\title{
Recent Advances in Novel Lateral Flow Technologies for Detection of COVID-19
}

\author{
Wesley Wei-Wen Hsiao ${ }^{1, *,+}+\mathbb{C}$, Trong-Nghia Le ${ }^{1,+}{ }^{-}$, Dinh Minh Pham ${ }^{2,3} \mathbb{C}^{-}$, Hui-Hsin Ko ${ }^{4}$, Huan-Cheng Chang ${ }^{1,5}$, \\ Cheng-Chung Lee ${ }^{4}$, Neha Sharma ${ }^{1}$, Cheng-Kang Lee ${ }^{1}$ and Wei-Hung Chiang ${ }^{1, *}$ (])
}

1 Department of Chemical Engineering, National Taiwan University of Science and Technology, Taipei 106, Taiwan; letrongnghia720@gmail.com (T.-N.L.); hchang@gate.sinica.edu.tw (H.-C.C.); ns19jaipur@gmail.com (N.S.); cklee@mail.ntust.edu.tw (C.-K.L.)

2 GENTIS JSC, 249A, Thuy Khue, Tay Ho, Hanoi 100000, Vietnam; minhphd@gmail.com

3 Institute of Biotechnology, Vietnam Academy of Science and Technology, 18 Hoang Quoc Viet, Cau Giay, Hanoi 100000, Vietnam

4 Institute of Biological Chemistry, Academia Sinica, Taipei 115, Taiwan; fionako9220@gmail.com (H.-H.K.); chengung@gate.sinica.edu.tw (C.-C.L.)

5 Institute of Atomic and Molecular Sciences, Academia Sinica, Taipei 106, Taiwan

* Correspondence: weshsiao@mail.ntust.edu.tw (W.W.-W.H.); whchiang@mail.ntust.edu.tw (W.-H.C.)

+ These authors contributed equally to this work.

Citation: Hsiao, W.W.-W.; Le, T.-N.; Pham, D.M.; Ko, H.-H.; Chang, H.-C.; Lee, C.-C.; Sharma, N.; Lee, C.-K.; Chiang, W.-H. Recent Advances in Novel Lateral Flow Technologies for Detection of COVID-19. Biosensors 2021, 11, 295. https://doi.org/ 10.3390/bios11090295

Received: 24 July 2021

Accepted: 22 August 2021

Published: 25 August 2021

Publisher's Note: MDPI stays neutral with regard to jurisdictional claims in published maps and institutional affiliations.

Copyright: (c) 2021 by the authors. Licensee MDPI, Basel, Switzerland. This article is an open access article distributed under the terms and conditions of the Creative Commons Attribution (CC BY) license (https:// creativecommons.org/licenses/by/ $4.0 /)$.
Abstract: The development of reliable and robust diagnostic tests is one of the most efficient methods to limit the spread of coronavirus disease 2019 (COVID-19), which is caused by the severe acute respiratory syndrome coronavirus-2 (SARS-CoV-2). However, most laboratory diagnostics for COVID-19, such as enzyme-linked immunosorbent assay (ELISA) and reverse transcriptase-polymerase chain reaction (RT-PCR), are expensive, time-consuming, and require highly trained professional operators. On the other hand, the lateral flow immunoassay (LFIA) is a simpler, cheaper device that can be operated by unskilled personnel easily. Unfortunately, the current technique has some limitations, mainly inaccuracy in detection. This review article aims to highlight recent advances in novel lateral flow technologies for detecting SARS-CoV-2 as well as innovative approaches to achieve highly sensitive and specific point-of-care testing. Lastly, we discuss future perspectives on how smartphones and Artificial Intelligence (AI) can be integrated to revolutionize disease detection as well as disease control and surveillance.

Keywords: COVID-19; SARS-CoV-2; lateral flow assay; point-of-care testing; artificial intelligence

\section{Introduction}

The outbreak of coronavirus disease 2019 (COVID-19) caused by the severe acute respiratory syndrome coronavirus-2 (SARS-CoV-2) has had a detrimental effect on human health and interrupted regular social activities. Since the virus was first identified in Wuhan, China, in December 2019, the disease has spread globally and, according to the World Health Organization (WHO), has resulted in more than 4 million deaths (as of July 2021) [1]. COVID-19 is a potentially fatal respiratory illness with a broad spectrum of symptoms, which can include high fever, exhaustion, and a dry cough. These symptoms are the same as those caused by other respiratory illnesses (common cold, season allergies, influenza), making it difficult to distinguish from other ailments. Research has shown that patients who are suffering from other diseases, such as cancer, cardiovascular disease, and diabetes, or elderly patients are more likely to develop severe symptoms that require hospitalization [2].

The SARS-CoV-2 virus is transmitted through respiratory droplets, aerosols, or close contact with infected individuals. Recent studies demonstrate that infected patients, whether symptomatic or asymptomatic, may be contagious [3,4]. Mizumoto et al. reported that in the Diamond Princess cruise ship cluster, $18 \%$ of positive cases were recognized 
as asymptomatic [5]. In another cluster on an Argentinian cruise ship, 128 passengers tested positive for COVID-19. Among the COVID-19-positive patients, 104 positive cases $(81 \%)$ were recognized as asymptomatic [6]. Therefore, accurate and effective diagnosis at COVID-19's early stages is critical for reducing the risk of transmission, as it allows for quick isolation, contact tracing, and earlier treatment. An ideal diagnostic technique would be cost-effective, portable, rapid, and robust with high sensitivity and specificity $[7,8]$. This would allow for point-of-care (POC) testing and patient self-administration, resulting in rapid and adequate results and better epidemiological surveillance.

Currently available diagnostic techniques for COVID-19 are based on the detection of the viral gene, antigen, or human antibodies (serological test) and human metabolites [9-16]. Among these techniques, the detection of viral RNA sequences by reverse transcription polymerase chain reaction (RT-PCR), reverse transcription loop-mediated isothermal amplification (RT-LAMP), and reverse transcription quantitative polymerase chain reaction (RT-qPCR) have been the most reliable methods. RT-qPCR uses signal amplification to achieve a high degree of accuracy [17-19]. RT-LAMP is a newly established technique in which amplification occurs at a single temperature [20-22]. RT-qPCR is able to directly detect SARS-CoV-2 by monitoring the amplification of a targeted DNA molecule during the PCR [13]. Moreover, some novel technologies for detecting viral gene, such as next-generation sequencing (NGS) and Clustered Regularly Interspaced Short Palindromic Repeats (CRISPR), draw great attention due to their better accuracy and higher throughput $[23,24]$. However, these methods are expensive, time-consuming, and limited to well-trained professional operators. Therefore, they are often not amenable to extensive population-based or POC testing [25,26].

Virus antigens or host antibodies can also be detected serologically. The enzymelinked immunosorbent assay (ELISA) is a rapid and inexpensive technique for detecting specific antibodies in blood samples. In a recent study, an ELISA test was used to detect human SARS-CoV-2 seroconverters [27]. This test enabled the detection of distinct antibody types as early as three days after the onset of symptoms. However, similar to RT-PCR techniques, the ELISA method also needs to be performed by well-trained personnel. It also relies on specialized equipment, making it difficult to use at POC testing.

Among available POC testing techniques, the lateral flow immunoassay (LFIA) has been extensively researched and used for COVID-19 diagnosis, owing to its low cost, speed, and accessibility [13,14,25]. To diagnose COVID-19, lateral flow tests combine SARS-CoV-2 pathogen assays with antibodies in patients. LFIA tests usually take around 10-30 min, while the conventional ELISA takes approximately $2-5 \mathrm{~h}$. The sensitivity of COVID-19 detection by LFIA ranges from 61\% to $88 \%$ (10 days after the first onset of symptoms) to $100 \%$ (after 3 weeks) [28,29]. However, early detection of the disease is a real challenge for LFIA, due to its low accuracy in detection. The accuracy of an LFIA device is evaluated in terms of its sensitivity and specificity. Thus, many efforts have been made to achieve higher sensitivity and specificity for SARS-CoV-2 detection in order to reduce false negative/positive predictive results. In a recent report, Xiang et al. showed that redesigned LFIA can obtain comparable sensitivity to ELISA [30]. Similarly, Smith et al. evaluated the sensitivity of the Quidel SARS Sofia rapid antigen flow immunoassay (USA) against RT-qPCR [31]. All tests achieved higher than 98\% sensitivity to detect infected patients if tests were administered every three days. These evaluations confirmed the possibility of developing an ultrasensitive, highly specific LFIA for POC testing.

Since the use of RT-PCR, ELISA, and other techniques in SARS-CoV-2 detection has been discussed in a number of reviews elsewhere $[9,11,13-15,17,18,25]$, in this article, we focus on recent advances in the development of novel lateral flow techniques as well as methods of increasing its sensitivity and specificity. Lastly, the next generation of POC testing for detecting COVID-19, such as smart phones and Artificial Intelligence (AI), will also be discussed. 


\section{Lateral Flow Technologies/Assays}

Lateral flow technology (also known as lateral flow assay) plays a critical role in POC testing, as the technique is rapid, cost-effective, and can be operated by untrained personnel. In this article, depending on the analytes being targeted, lateral flow technologies can be classified as follows: lateral flow immunoassay (LFIA), nucleic acid lateral flow assay (NLFA), and nucleic acid lateral flow immunoassay (NALFIA). LFIA is able to detect antibodies/antigens, while NLFA uses a DNA or RNA probe to detect nucleic acid. Moreover, NALFIA uses both antibodies/antigens and nucleic acid as biomarkers for the detection of antigens/antibodies or amplicons [25].

\section{Lateral Flow Immunoassay (LFIA)}

Lateral flow immunoassay (LFIA), a qualitative chromatography, is a very simple, rapid, portable analytical platform that specifically targets the detection of antigens or antibodies [32,33]. LFIA was first reported in the early 1980s and commercialized in 1984 as the first product for a urine-based pregnancy test via the detection of human chorionic gonadotropin (hCG) [34]. Since then, over thousands of LFIA devices have been reported and applied toward the diagnosis and prognosis of various infectious diseases, cardiac diseases, tumors, pathogens, pesticides, toxins, and metal ions [35].

LFIAs are typically composed of a sample pad, a conjugated pad, a nitrocellulose (NC) membrane, and an absorbent pad, as shown in Figure 1 [36,37]. As a paper-based chromatography, LFIA utilizes capillary forces to transport a fluid sample across various strip zones. Based on its design, LFIA could either detect the desirable antibodies or antigens through antibody-antigen interactions. The liquid sample is introduced to the sample pad of the strip and flows through the conjugated pad on which the targeted antibodies or antigens are conjugated with color or fluorescent reporter. Then, the complex reaches the NC membrane, where specific antibodies or antigens are fixed at a specified area, called the test line. Additionally, a control line is conjugated further along the NC membrane. If the targeted antibodies or antigens are contained in the sample, the forming reported antibody-antigen complex will induce color/fluorescent formation at the test line of the strip. Meanwhile, a proper formation of the control line indicates a properly conducted test. Additional test lines can also be immobilized to the NC membrane, allowing the detection of multiple antibodies/antigens in a single run. For quantification, the test strip is applied for optical/fluorescent reader for measurement of the color/fluorescent intensity [38,39].

Currently, two common models of LFIA have been proposed, similar to ELISA, including competitive and sandwich models, as shown in Figure 2. The competitive assay that is designed for antigens has only one epitope that cannot simultaneously bind with two antibodies [40]. In the presence of analyte, the antibody-antigen interaction is formed, inhibiting the signal formation at the test line. Therefore, in the competitive test, the signal intensity is inversely proportional to the concentration of analyte in the sample. On the other hand, sandwich assay is used for analyte antigens, which has two epitopes that can simultaneously bind with two distinct types of antibodies, such as hCG used in pregnancy tests [41]. The targeted antigen is trapped between two antibodies at the test line, and therefore, the signal intensity is proportional to the amount of analyte in the sample. 


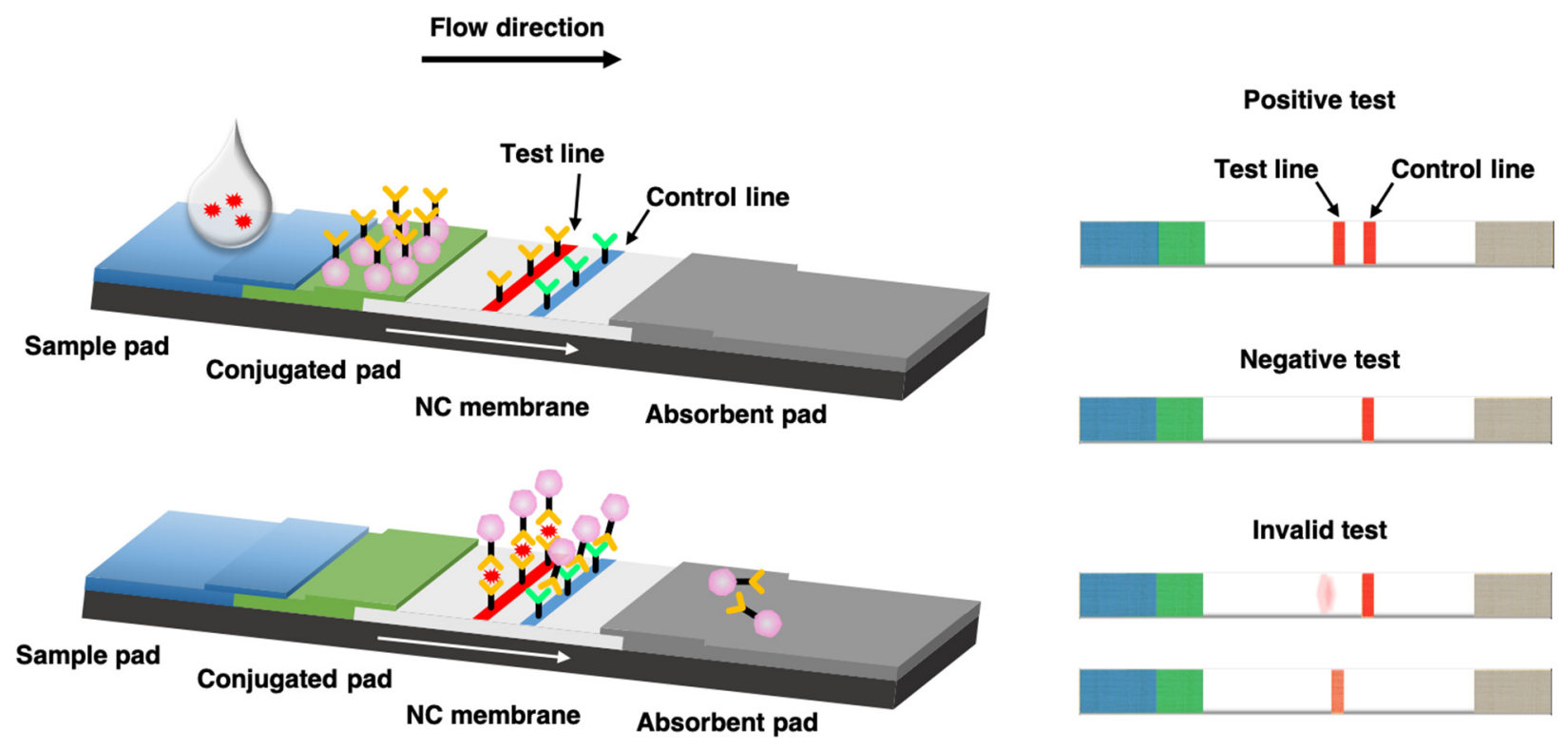

Figure 1. Schematic illustration of an antigen detection-based LFIA test.

Competitive

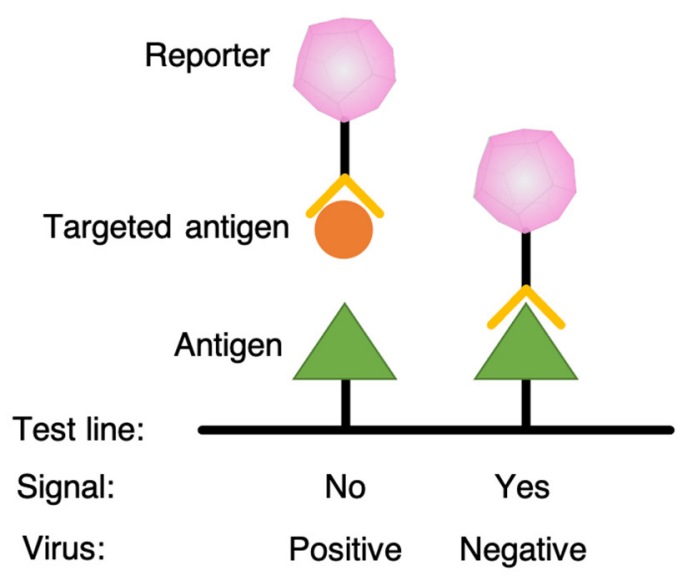

Sandwich

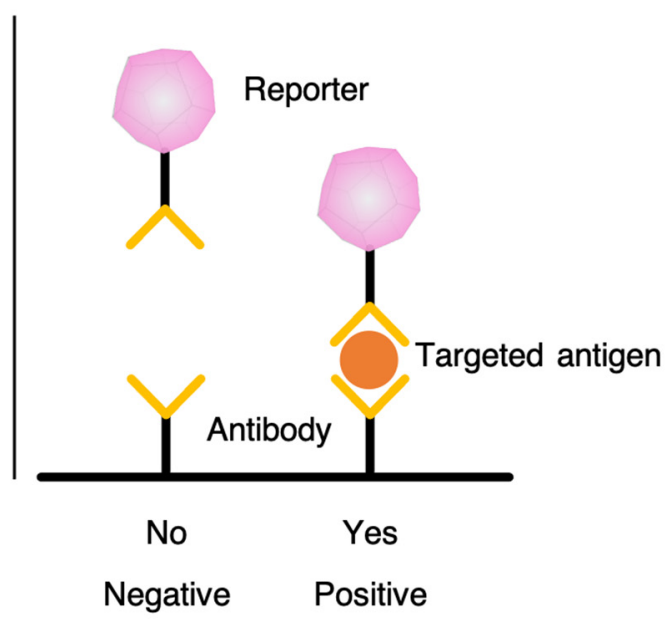

Figure 2. The competitive assay and sandwich assay models.

Many liquid biological samples, including urine, saliva, perspiration, serum, plasma, whole blood, and other fluids, can also be analyzed with LFIA [42-44]. Numerous nanoparticles (NPs), including colloidal gold nanoparticles (AuNPs), quantum dots (QDs), fluorescent nanodiamond (FND), carbon black, selenium nanoparticles, and lanthanide-doped phosphors, have been employed as reporters. The conventional method uses AuNPs as a visual reporter for most assays $[45,46]$. AuNPs are easily functionalized. They also have enhanced stability, higher values for charge transfer, and good optical sensitivity. However, due to the technique's low accuracy, significant improvements are required to make AuNPs suitable for diagnosing disease at its early stages.

\section{Lateral Flow Technologies for COVID-19 Detection}

\subsection{Gene Detection}

Using an NLFA, Yu et al. simultaneously detected three genes of the SARS-CoV-2 virus, including RdRp, ORF3a, and N protein gene [47]. The assay obtained a detection limit of 10 copies per test for each gene after $30 \mathrm{~min}$. However, amplification using RT-PCR or some other technique was required prior to the NLFA process. In addition to high sensitivity 
and specificity, simultaneous detection was enabled to avoid false positive results due to the cross-reactivity of SARS-CoV-2, as well as false negative results due to the SARS-CoV-2 genome mutation. NFLIAs have also been studied for COVID-19 detection [48,49]. In another study, Wang et al. reported a nucleic acid immunoassay for detecting RNA of SARS-CoV-2 based on the binding of DNA probes to three genes (ORF3a, E protein gene, and $\mathrm{N}$ protein gene) without engaging in the pre-amplification process [49]. Then, SARSCoV-2 antibodies were conjugated with europium chelate fluorescent nanoparticles and bound to the DNA-RNA hybrids. When testing with throat samples, the assay showed high sensitivity with a detection limit of 500 copies per $\mathrm{mL}$ in less than $1 \mathrm{~h}$. Additionally, detecting three genes also helped avoid false positive results, making this technique a good candidate for POC testing. Several reports of SARS-CoV-2 are listed in Table 1.

Table 1. Selected laboratory prototypes of lateral flow tests for COVID-19 detection.

\begin{tabular}{|c|c|c|c|c|c|c|c|c|}
\hline Type & Reporter & Biomarker & Detection Method & $\begin{array}{l}\text { Detection } \\
\text { Limit }\end{array}$ & Sensitivity & Specificity & $\begin{array}{l}\text { Test } \\
\text { Time }\end{array}$ & Ref. \\
\hline \multirow{3}{*}{ 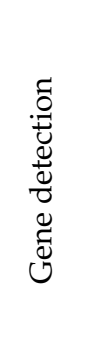 } & Cy5 & $\begin{array}{l}\text { RdRp, } \\
\text { ORF3a, N } \\
\text { gene }\end{array}$ & Fluorescence & $\begin{array}{l}10 \text { copies } \\
\text { per test }\end{array}$ & $100 \%$ & $99 \%$ & $30 \mathrm{~min}$ & [47] \\
\hline & $\begin{array}{l}\text { Crimson } \\
\text { red-coated } \\
\text { polymer NPs }\end{array}$ & $\begin{array}{l}\text { ORF1ab, N } \\
\text { gene }\end{array}$ & Visual/optical reader & $\begin{array}{l}12 \text { copies } \\
\text { per reaction }\end{array}$ & $100 \%$ & $100 \%$ & $1 \mathrm{~h}$ & [48] \\
\hline & $\begin{array}{l}\text { Europium } \\
\text { chelate NPs }\end{array}$ & $\begin{array}{l}\text { E gene, } \mathrm{N} \\
\text { gene }\end{array}$ & Fluorescence & $\begin{array}{l}500 \text { copies } \\
\text { per mL }\end{array}$ & $100 \%$ & $99 \%$ & $<1 \mathrm{~h}$ & [49] \\
\hline \multirow{3}{*}{ 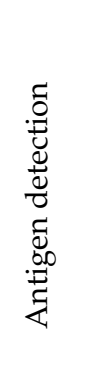 } & Glyco-AuNPs & S proteins & Visual/optical reader & $5 \mu \mathrm{g} \mathrm{mL} L^{-1}$ & - & $100 \%$ & $5-30 \mathrm{~min}$ & {$[50]$} \\
\hline & $\begin{array}{l}\text { Carboxylate- } \\
\text { modified } \\
\text { polystyrene } \\
\text { europium (III) } \\
\text { chelate } \\
\text { microparticles }\end{array}$ & $\mathrm{N}$ proteins & Fluorescence & - & $68 \%$ & $100 \%$ & $10 \mathrm{~min}$ & [51] \\
\hline & Latex bead & $\mathrm{N}$ proteins & Visual/optical reader & $\begin{array}{c}0.65 \mathrm{ng} \\
\mathrm{mL}^{-1}\end{array}$ & - & - & - & [52] \\
\hline \multirow{10}{*}{ 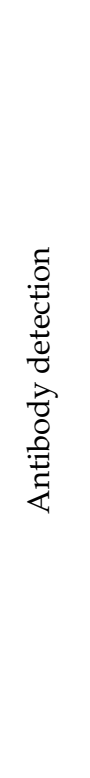 } & AuNPs & $\operatorname{IgG}, \operatorname{IgM}$ & Visual & - & $82.4 \%$ & $100 \%$ & $10 \mathrm{~min}$ & {$[30]$} \\
\hline & AuNPs & IgG, IgM & Visual & - & $88.7 \%$ & $90.6 \%$ & $15 \mathrm{~min}$ & [53] \\
\hline & AuNPs & $\operatorname{IgG}$ & Visual & - & $69.1 \%$ & $100 \%$ & $\begin{array}{l}15-20 \\
\min \end{array}$ & [54] \\
\hline & AuNPs & $\begin{array}{l}\text { IgG, IgM, } \\
\text { IgA }\end{array}$ & Visual/optical reader & - & $94.6 \%$ & $100 \%$ & - & [55] \\
\hline & AuNPs & $\operatorname{Ig} \mathrm{A}$ & $\begin{array}{l}\text { Visual/optical reader, } \\
\text { chemiluminescence }\end{array}$ & - & - & - & $15 \mathrm{~min}$ & [56] \\
\hline & AuNPs & $\operatorname{IgM}$ & Visual & & $100 \%$ & $93.3 \%$ & $15 \mathrm{~min}$ & [57] \\
\hline & AuNPs & IgG, IgM & Visual, laser readout & $\begin{array}{c}4 \times 10^{8} \\
\text { molecules }\end{array}$ & $\begin{array}{l}0.1 \mathrm{ng} \\
\mathrm{mL}^{-1}\end{array}$ & - & - & [58] \\
\hline & AuNPs & IgG, IgM & POC testing system & - & $96.6 \%$ & $100 \%$ & $15 \mathrm{~min}$ & [59] \\
\hline & AuNPs & $\begin{array}{l}\text { IgG, IgM, } \\
\operatorname{IgA}\end{array}$ & $\begin{array}{l}\text { Visual, lateral flow } \\
\text { reader }\end{array}$ & - & $100 \%$ & $98.2 \%$ & $30 \mathrm{~min}$ & [60] \\
\hline & QDs & IgG, IgM & $\begin{array}{l}\text { Portable fluorescence } \\
\text { smartphone system }\end{array}$ & - & $99 \%$ & $100 \%$ & $15 \mathrm{~min}$ & [61] \\
\hline
\end{tabular}


Table 1. Cont.

\begin{tabular}{|c|c|c|c|c|c|c|c|c|}
\hline Type & Reporter & Biomarker & Detection Method & $\begin{array}{l}\text { Detection } \\
\text { Limit }\end{array}$ & Sensitivity & Specificity & $\begin{array}{l}\text { Test } \\
\text { Time }\end{array}$ & Ref. \\
\hline & QD nanobeads & $\begin{array}{c}\text { Total } \\
\text { antibodies }\end{array}$ & Fluorescence & - & $97.1 \%$ & $100 \%$ & $15 \mathrm{~min}$ & [62] \\
\hline & $\begin{array}{c}\mathrm{SiO}_{2} @ \mathrm{Au} @ \mathrm{QD} \\
\text { nanobeads }\end{array}$ & IgG, IgM & Visual, fluorescence & - & $100 \%$ & $100 \%$ & $15 \mathrm{~min}$ & [63] \\
\hline & $\begin{array}{l}\text { Lanthanide- } \\
\text { doped } \\
\text { polystyrene } \\
\text { NPs }\end{array}$ & $\operatorname{IgG}$ & Fluorescence & - & - & - & $10 \mathrm{~min}$ & [64] \\
\hline & Selenium NPs & IgG, IgM & Visual & - & $94.7 \%$ & $95.1 \%$ & - & [65] \\
\hline & AIE NPs & $\operatorname{IgG}, \operatorname{IgM}$ & Fluorescence & $\begin{array}{c}0.125 \mu \mathrm{g} \\
\mathrm{mL}^{-1}\end{array}$ & $95 \%$ & - & - & [66] \\
\hline & $\begin{array}{c}\mathrm{SiO}_{2} @ \mathrm{Ag} \\
\text { nanocomposite }\end{array}$ & $\operatorname{IgG}, \operatorname{IgM}$ & $\begin{array}{c}\text { Surface-enhanced } \\
\text { Raman spectroscopy }\end{array}$ & - & $100 \%$ & $100 \%$ & - & [67] \\
\hline
\end{tabular}

\subsection{Antigen Detection}

Although many LFIAs for COVID-19 detection have been investigated and commercialized, there are only a few studies on antigen detection. The spike surface glycoproteins (S) and nucleocapsid proteins (N) of SARS-CoV-2 are the most commonly targeted antigens for antigen and serological tests. The characteristics of several reported LFIA devices for SARS-CoV-2's antigen detection are shown in Table 1. For instance, Baker et al. used glycan as a binding agent to capture SARS-CoV-2 spike glycoprotein [50]. This LFIA device obtained $100 \%$ specificity with a detection limit of $5 \mu \mathrm{g} \mathrm{mL} \mathrm{m}^{-1}$. In another study, Diao et al. used N protein as a biomarker to detect SARS-CoV-2 in nasopharyngeal swabs and urine samples from patients with a suspected SARS-CoV-2 infection [51]. Carboxylate-modified polystyrene europium (III) chelate microparticles were used as fluorescent reporters. The test line and control line were constructed with the mouse anti-N protein of SARS-CoV-2 monoclonal antibody and the goat anti-rabbit IgG antibodies, respectively. The assay can be performed in 10 min with $100 \%$ specificity and $68 \%$ sensitivity compared to nucleic acid tests. In addition, latex beads are utilized as color reporters for $\mathrm{N}$ protein antigen detection with a detection limit of $0.65 \mathrm{ng} \mathrm{mL}^{-1}$ [52]. Overall, these assays are less sensitive than ELISA and RT-PCR tests. Hence, these tests are less popular than antibody detection-based LFIA and have a lower market share.

\subsection{Antibody Detection}

Immunoglobulin M (IgM) antibodies and Immunoglobulin G (IgG) antibodies are two common types of antibodies generated by the human immune system. A number of LFIAs have been developed for detecting antibodies in the blood of patients who are exposed to the SARS-CoV-2 virus. However, focusing on antibody detection may lead to false negative tests when the disease is at its early stages. This is because in the days immediately following infection, antibodies might be below detectable levels, as shown in Figure $3[68,69]$. It has been demonstrated that 2-3 days after the onset of symptoms, the levels of IgM antibodies (as surveillance antibodies) rise, reaching its peak after 2 weeks [70]. Nevertheless, the levels of IgM will quickly decrease within 3 weeks. In contrast, the levels of IgG antibodies (as attack antibodies) increase 10-14 days after the first onset of symptoms. Then, the levels of IgG remain elevated for 4-5 weeks and decrease and stabilize after 5-6 weeks. 


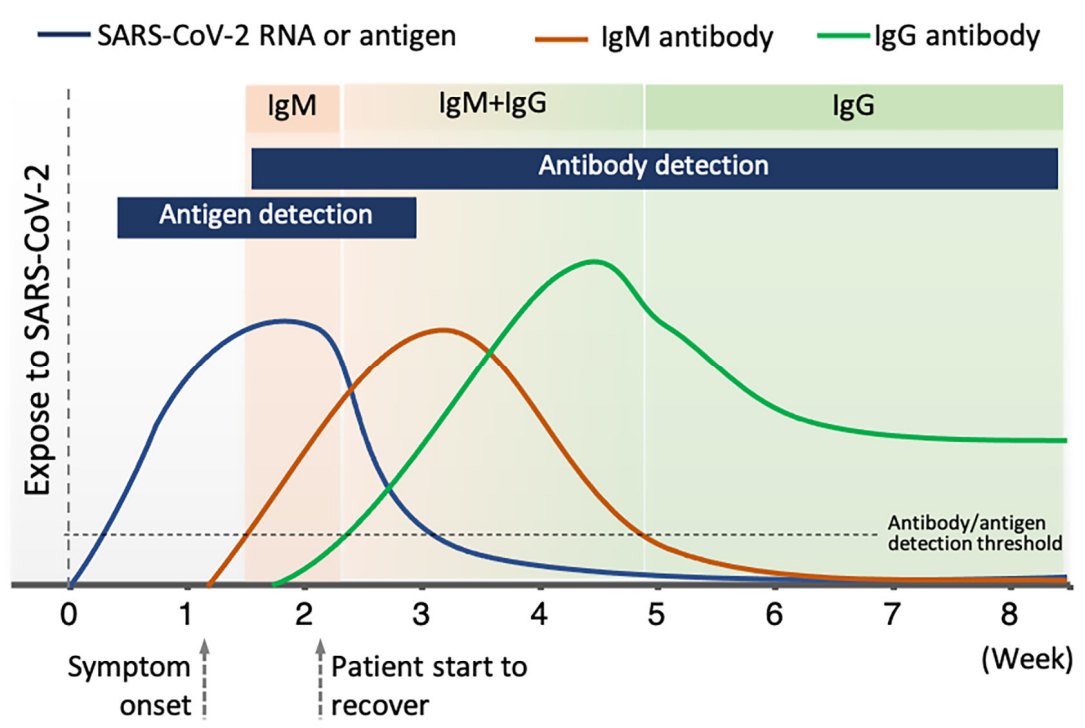

Figure 3. Levels of antibody and antigen at different clinical stage of COVID-19 disease.

Thus, to avoid false negatives, the test needs to be performed at least 14 days after the first symptom. False positive results caused by cross-reactivity are also an important problem for these LFIA tests. For example, the similarity between the target SARS-CoV-2 antigen and other coronavirus antigens (such as SARS-CoV-1, MERS-CoV, HCoV-HKU1, HCoV-OC43, HCoV-NL63, and HCoV-229E) may impact the accuracy of LFIA tests [71]. The specificity of the antigen-antibody interaction is another crucial factor that directly correlates to the LFIA test's efficiency. For instance, S1 subunits have higher specificity than N proteins for detecting SARS-CoV-2 antibodies [69]. Despite these limitations, many researchers and biotech companies have focused on antibody detection in COVID-19 diagnosis, which can be used to screen asymptomatic infected individuals to prevent possible spread of COVID-19. Several publications on the development of LFIAs that detect SARS-CoV-2 antibodies are also shown in Table 1.

In a recent study, Wen et al. put forward a method of rapid antibody detection for SARS-CoV-2. This process only takes $15-20 \mathrm{~min}$ and produces a visual readout [54]. In this study, AuNPs were used as reporters and were conjugated with mouse anti-human IgG (mAbs). This test had $69.1 \%$ sensitivity and $100 \%$ specificity. Furthermore, Li et al. combined the detection of $\operatorname{IgG}$ and IgM antibodies to facilitate higher sensitivity compared to a single antibody test [53]. As shown in Figure 4, a control line (anti-rabbit IgG), an IgG test line (anti-human IgG), and an IgM test line (anti-human IgM) were printed on the NC membrane. Once again, AuNPs were used as reporters. When run with a SARS-CoV-2 containing sample, IgG antibodies bound to the antigen-conjugated AuNPs and were captured at the IgG test line. Similarly, IgM-containing samples were captured at the IgM test line. In this work, $88.7 \%$ sensitivity and $90.6 \%$ specificity were obtained. The sensitivity of the IgG-IgM combined test showed higher sensitivity than single IgG or IgM detection. 
(A)

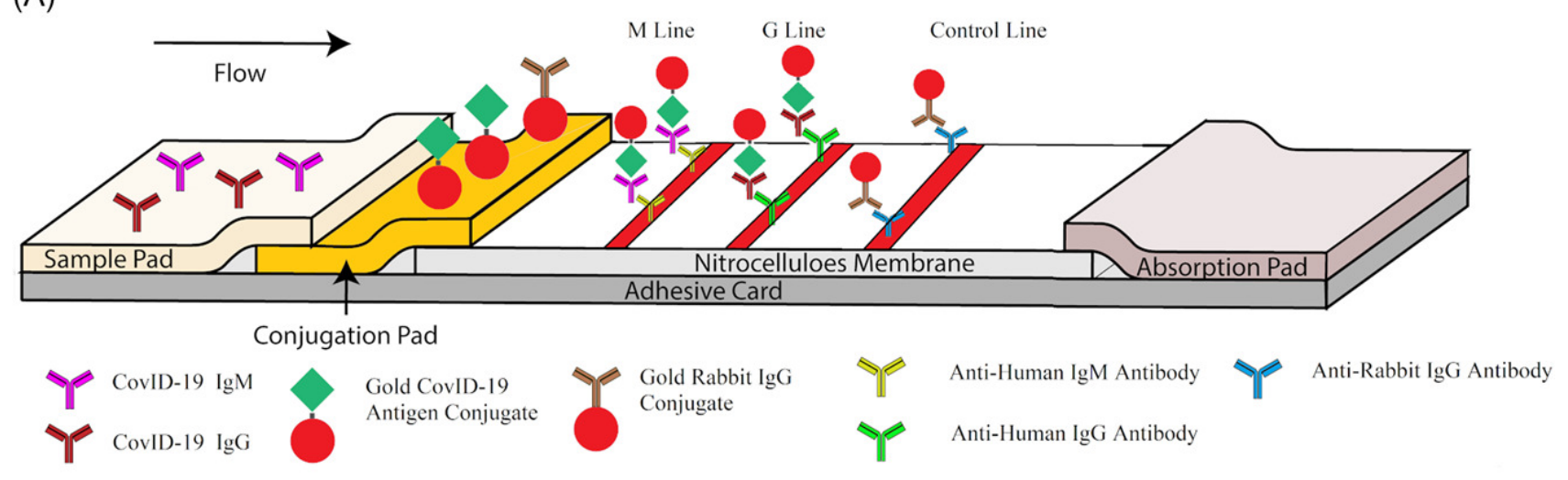

(B)

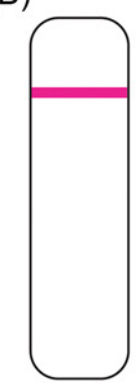

Negative

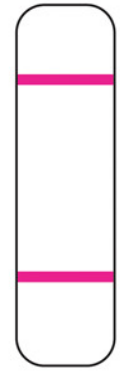

$\lg \mathrm{M}$ Positive

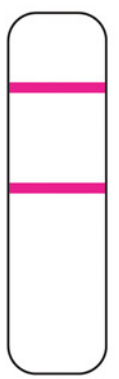

$\lg G$ Positive

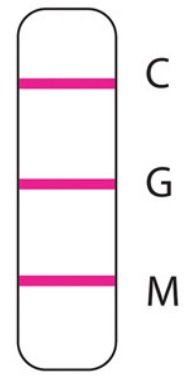

$\lg M / \lg G$ Positive

Figure 4. IgM-IgG combined antibody test for SARS-CoV-2 detection. (A) Schematic illustration of the LFIA device; (B) Results generated from the LFIA test. C: control line, G: IgG line, M: IgM line. Reprinted from [53].

In order to achieve higher sensitivity, Calvalera et al. developed a multi-targeted LFIA that allows for the detection of total antibodies, including IgG, IgM, and IgA [55]. Staphylococcal protein A (SpA) and N protein of SARS-CoV-2 were used to construct the $\mathrm{T} 1$ and T2 test line, respectively (Figure 5). The control line consisted of avidin. AuNPs were labeled with $\mathrm{N}$ protein and biotin to act as reporters. SpA has been reported to bind with either human IgG antibody through Fc domain or IgM and IgA antibodies through Fab domains. Hence, the use of SpA and $\mathrm{N}$ protein antigen enables multi-target ability, and it results in a high sensitivity of $94.6 \%$ and $100 \%$ specificity. In addition, with the detection of IgA, the LFIA device seems to be a good early predictor of SARS-CoV-2, since IgA is known to be produced at detectable levels earlier than IgG and IgM [72]. 
a

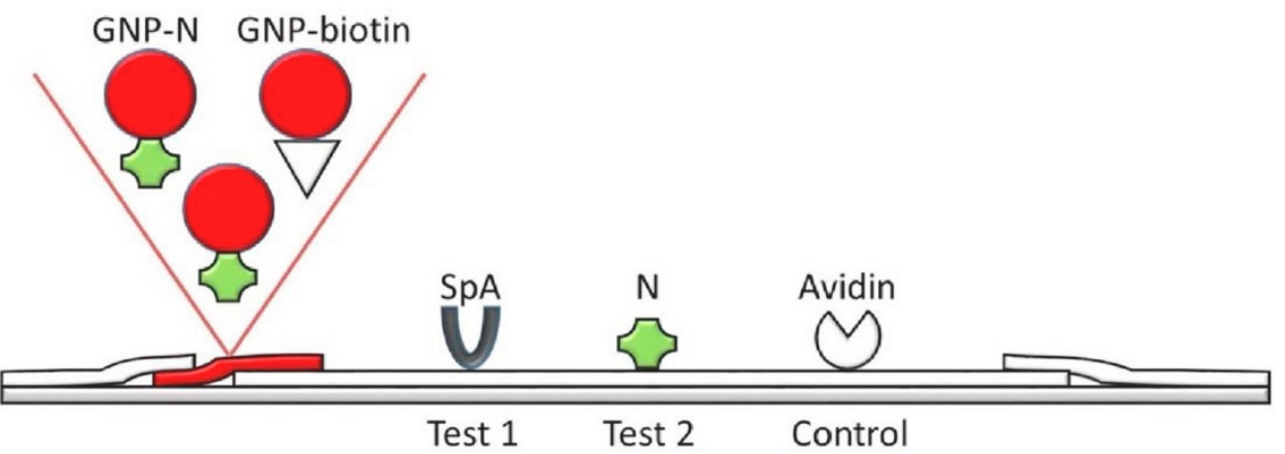

b NegAtive SAMPLE

Generic

human

antibodies

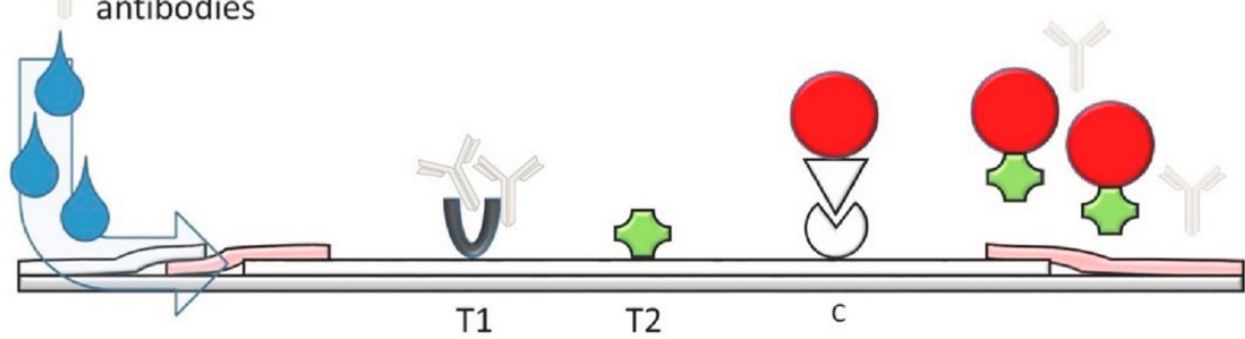

\section{POSITIVE SAMPLE}

Anti SARS CoV-

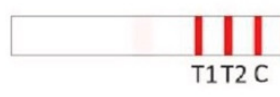

2 human antibodies T1 T2 C

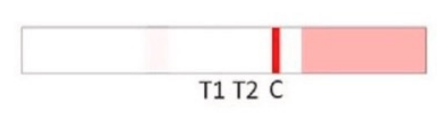

T1

$\mathrm{T} 2$ (IgA, IgG, IgM)
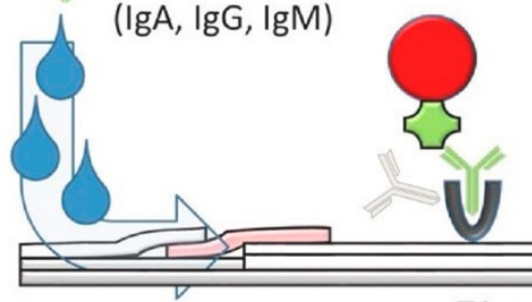

T1

$\mathrm{T} 2$
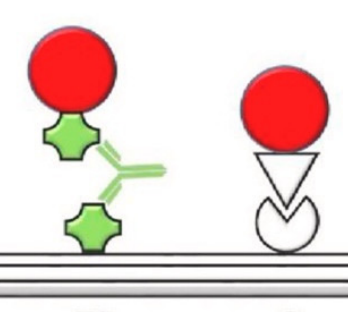

C

Figure 5. LFIA device for the rapid serological IgG, IgM, and IgA detection of SARS-CoV-2. (a) Protein A (SpA), SARS-CoV-2 N protein, and avidin were printed on the membrane for the T1 test line, T2 test line, and control line, respectively. N protein-labeled AuNPs and biotin-labeled AuNPs were used as reporters. (b) Negative test results consist of a single visible control line. (c) Positive test results showed three visible lines, indicating the simultaneous binding of antibodies (IgG, IgM, and IgA) to the T1 and T2 test line. Reprinted from with permission from [55]. Copyright 2020, Elsevier.

Due to their rapid and low-cost properties, many LFIA devices have been available on the market, as shown in Table 2. Some examples of antigen-based detection devices are the CareStart COVID-19 Antigen test (Access Bio, Inc., Somerset, NJ, USA), Siofia 2 Flu + SARS antigen flow immunoassay (Quidel Corporation, San Diego, CA, USA), and BinaxNOW COVID-19 Ag Card (Abbott Diagnostics Scarborough, Inc., Scarborough, ME, USA). These test kits have been issued Emergency Use Authorization (EUA) by the US Food and Drug Administration (FDA), and they have a detection limit ranging from $4.17 \times 10^{5}$ to $22.5 \mathrm{TCID}_{50} \mathrm{~mL}^{-1}$ (TCID $50: 50 \%$ tissue culture infective dose). The advantages of antigen detection kits are their low-cost, fast processing time (less than $20 \mathrm{~min}$ ), high sensitivity 
(84-97.6\%), and specificity (100\%) [73]. In a recent study, Smith et al. demonstrated that the Quidel SARS Sofia antigen flow immunoassay (USA) showed similar sensitivity and specificity to RT-qPCR, which is very promising [31]. However, these test kits require a sample preparation step, the use of a specific instrument, or need to be performed by a trained operator, which limits their large-scale application.

Table 2. Selected commercial lateral flow devices for COVID-19 detection.

\begin{tabular}{|c|c|c|c|c|c|c|c|}
\hline Type & Test Kit & Sample Type & Biomarker & $\begin{array}{l}\text { Detection } \\
\text { Method }\end{array}$ & Sensitivity & $\begin{array}{l}\text { Test } \\
\text { Time }\end{array}$ & Characteristics \\
\hline \multirow{4}{*}{ 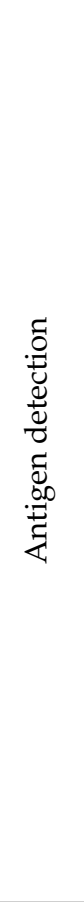 } & $\begin{array}{c}\text { BinaxNOW } \\
\text { COVID-19 Ag } \\
\text { Card, Abbott } \\
\text { Diagnostics } \\
\text { Scarborough, Inc. } \\
\text { [74] }\end{array}$ & Nasal swab & $\mathrm{N}$ protein & Visual & $\begin{array}{c}22.5 \\
\text { TCID }_{50} / \text { swab }\end{array}$ & $15 \mathrm{~min}$ & $\begin{array}{l}\text { POC testing; } \\
\text { performance } \\
\text { depends on } \\
\text { following careful } \\
\text { testing instructions }\end{array}$ \\
\hline & $\begin{array}{c}\text { CareStart } \\
\text { COVID-19 Antigen } \\
\text { test, Access Bio, } \\
\text { Inc. }[75]\end{array}$ & $\begin{array}{l}\text { Nasopharyngeal } \\
\text { Swab }\end{array}$ & $\mathrm{N}$ protein & Visual & $\begin{array}{c}8 \times 10^{2} \\
\mathrm{TCID}_{50} / \mathrm{mL}\end{array}$ & $10 \mathrm{~min}$ & $\begin{array}{l}\text { Requires sample } \\
\text { preparation step; } \\
\text { operated by } \\
\text { trained personnel }\end{array}$ \\
\hline & $\begin{array}{c}\text { Lumira Dx } \\
\text { SARS-CoV-2 Ag } \\
\text { Test, Lumira Dx } \\
\text { UK Ltd. [76] }\end{array}$ & Nasal swab & $\mathrm{N}$ protein & Fluorescence & $\begin{array}{c}32 \\
\mathrm{TCID}_{50} / \mathrm{mL}\end{array}$ & $12 \mathrm{~min}$ & $\begin{array}{l}\text { Requires Lumira } \\
\text { Dx Platform; } \\
\text { operated by } \\
\text { trained personnel }\end{array}$ \\
\hline & $\begin{array}{c}\text { Sofia } 2 \text { Flu + SARS } \\
\text { Antigen Flow } \\
\text { Immunoassay, } \\
\text { Quidel } \\
\text { Corporation [77] }\end{array}$ & $\begin{array}{l}\text { Nasal, } \\
\text { Nasopharyn- } \\
\text { geal } \\
\text { swabs }\end{array}$ & $\mathrm{N}$ protein & Fluorescence & $\begin{array}{c}4.17 \times 10^{5} \\
\operatorname{TCID}_{50} / \mathrm{mL}\end{array}$ & $15 \mathrm{~min}$ & $\begin{array}{c}\text { Detection of } \\
\text { SARS-CoV-2, } \\
\text { Influenza A Virus, } \\
\text { and Influenza B } \\
\text { Virus; limited to } \\
\text { Sofia } 2 \text { Instrument; } \\
\text { operated by } \\
\text { trained personnel }\end{array}$ \\
\hline \multirow{4}{*}{ 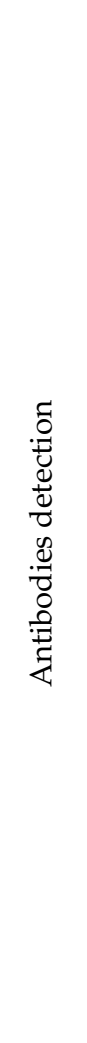 } & $\begin{array}{c}\text { Biohit SARS-CoV-2 } \\
\text { IgM/IgG Antibody } \\
\text { Test Kit, Biohit } \\
\text { Healthcare (Hefei) } \\
\text { Co., Ltd. [78] }\end{array}$ & $\begin{array}{c}\text { Serum, } \\
\text { plasma, } \\
\text { venous } \\
\text { whole blood } \\
\text { (heparin, } \\
\text { EDTA, and } \\
\text { sodium } \\
\text { citrate) }\end{array}$ & $\operatorname{IgM}$ and $\operatorname{IgG}$ & Visual & $96.7 \%$ & $\begin{array}{l}10-20 \\
\min \end{array}$ & $\begin{array}{l}\text { Operated by } \\
\text { trained personnel }\end{array}$ \\
\hline & $\begin{array}{c}\text { COVID-19 } \\
\text { IgG/IgM Rapid } \\
\text { Test Cassette, } \\
\text { Healgen Scientific } \\
\text { LLC [79] }\end{array}$ & $\begin{array}{c}\text { Serum, } \\
\text { plasma, } \\
\text { whole blood }\end{array}$ & IgM and IgG & Visual & $100 \%$ & $10 \mathrm{~min}$ & $\begin{array}{l}\text { Operated by } \\
\text { trained personnel }\end{array}$ \\
\hline & $\begin{array}{c}\text { Diagnostic Kit for } \\
\text { IgM/IgG Antibody } \\
\text { to Coronavirus } \\
\text { (SARS-CoV-2), } \\
\text { Zhuhai Livzon } \\
\text { Diagnostics Inc. } \\
\text { [80] }\end{array}$ & $\begin{array}{c}\text { Serum, } \\
\text { plasma, } \\
\text { venous } \\
\text { whole blood }\end{array}$ & IgM and IgG & Visual & $90.6 \%$ & $15 \mathrm{~min}$ & - \\
\hline & $\begin{array}{c}\text { qSARS-CoV-2 } \\
\text { IgG/IgM Rapid } \\
\text { Test, Cellex Inc. } \\
{[81]}\end{array}$ & $\begin{array}{c}\text { Serum, } \\
\text { plasma } \\
\text { (EDTA or } \\
\text { citrate), } \\
\text { venous } \\
\text { whole blood }\end{array}$ & IgM and IgG & Visual & - & $15 \mathrm{~min}$ & $\begin{array}{l}\text { Operated by } \\
\text { trained personnel }\end{array}$ \\
\hline
\end{tabular}


Table 2. Cont.

\begin{tabular}{|c|c|c|c|c|c|c|c|}
\hline Type & Test Kit & Sample Type & Biomarker & $\begin{array}{l}\text { Detection } \\
\text { Method }\end{array}$ & Sensitivity & $\begin{array}{l}\text { Test } \\
\text { Time }\end{array}$ & Characteristics \\
\hline & $\begin{array}{c}\text { Sienna-Clarity } \\
\text { COVIBLOCK } \\
\text { COVID-19 } \\
\text { IgG/IgM Rapid } \\
\text { Test Cassette, } \\
\text { Salofa Oy [82] }\end{array}$ & $\begin{array}{c}\text { Serum, } \\
\text { plasma, } \\
\text { fingerstick } \\
\text { whole blood }\end{array}$ & IgM and IgG & Visual & $93.3 \%$ & $\begin{array}{l}15-20 \\
\min \end{array}$ & $\begin{array}{l}\text { Operated by } \\
\text { trained personnel }\end{array}$ \\
\hline & $\begin{array}{l}\text { SARS-CoV-2 IgG } \\
\text { IgM Antibody } \\
\text { Rapid Test Kit, } \\
\text { Lumigenex Co., } \\
\text { Ltd. [83] }\end{array}$ & $\begin{array}{c}\text { Serum, } \\
\text { plasma, } \\
\text { fingerstick } \\
\text { whole blood }\end{array}$ & IgM and IgG & Visual & $100 \%$ & $15 \mathrm{~min}$ & $\begin{array}{l}\text { Operated by } \\
\text { trained personnel }\end{array}$ \\
\hline & $\begin{array}{l}\text { SARS-CoV-2 } \\
\text { Antibody Test, } \\
\text { Guangzhou } \\
\text { Wondfo Biotech } \\
\text { Co., Ltd. [84] }\end{array}$ & $\begin{array}{c}\text { Serum, } \\
\text { plasma, } \\
\text { whole blood }\end{array}$ & IgM and IgG & Visual & $86.4 \%$ & $15 \mathrm{~min}$ & - \\
\hline & $\begin{array}{c}\text { RapCov Rapid } \\
\text { COVID-19 Test, } \\
\text { ADVAITE, Inc. } \\
\text { [85] }\end{array}$ & $\begin{array}{l}\text { Fingerstick } \\
\text { whole blood }\end{array}$ & $\operatorname{IgG}$ & Visual & $90 \%$ & $15 \mathrm{~min}$ & $\begin{array}{l}\text { Operated by } \\
\text { trained personnel }\end{array}$ \\
\hline & $\begin{array}{c}\text { Rapid COVID-19 } \\
\text { IgM/IgG Combo } \\
\text { Test Kit, Megna } \\
\text { Health, Inc. [86] }\end{array}$ & $\begin{array}{l}\text { Serum, acid } \\
\text { citrate } \\
\text { dextrose } \\
\text { plasma, } \\
\text { fingerstick } \\
\text { whole blood }\end{array}$ & IgM and IgG & Visual & $100 \%$ & $\begin{array}{l}10-20 \\
\min \end{array}$ & $\begin{array}{l}\text { Operated by } \\
\text { trained personnel }\end{array}$ \\
\hline
\end{tabular}

In a comparison study, the average sensitivity of commercial kits $(\approx 65 \%)$ was lower than the sensitivity of laboratory-based kits $(\approx 88 \%)$ and of other serological methods $(>80 \%)$ [87]. Moreover, although the claimed sensitivity and specificity of some commercial kits are high, the clinical accuracy of COVID-19 diagnosis is much lower, with the positive predictive value ranging from $11 \%$ to $50 \%$ [88]. In addition, LFIA detection devices are also associated with other challenges relating to difficulties controlling the fluid velocity and capillary force; the interferent porous membrane; the analysis time; and the sample nature $[89,90]$. Therefore, further efforts are needed to enhance the sensitivity and specificity of LFIA and ensure LFIA's practical application in disease control and surveillance.

\section{Enhancement of Sensitivity and Specificity}

During the COVID-19 pandemic and beyond, the need for low-cost, simple, rapid, and highly accurate methods of disease detection is urgent. However, false negative and false positive test results due to low sensitivity and specificity make it difficult for lateral flow devices to detect disease at its early stages. Therefore, results of lateral flow devices should be confirmed with RT-PCR before they are used to inform decision-making surrounding isolation and treatment. Up to now, many efforts have been made to enhance the sensitivity and specificity of lateral flow technologies. Several methods have been developed, such as sample pre-concentration and amplification, signal enhancement using nanoparticles or an external signal reader, optimizing assay time, and the use of high affinity agents [88]. 


\subsection{Sample Pre-Concentration and Pre-Amplification}

If the same quantity of sample is used, conventional lateral flow technologies only achieve an average sensitivity of $66 \%$, which is much lower than other serological assays. However, pre-concentration of the sample, before it is processed with lateral flow test, can significantly improve the assay's sensitivity. Sharma et al. have used a magnetic field to preconcentrate the analytes from the sample matrices to achieve 10 times higher sensitivity [91]. Furthermore, Mashayekhi et al. proposed to add Triton X-114 to concentrate the proteins by forming a two-phase micellar system to increase detection limits [92]. In the detection of transferrin, the detection limit of the lateral flow assay was significantly improved from 0.5 to $0.05 \mu \mathrm{g} \mathrm{mL}^{-1}$. By changing the volume ratio of these two micellar phases, these methods could potentially be leveraged to detect other proteins. In addition, the antigen-reporter complex can also be concentrated during the lateral flow assay running process by applying an electric field. The so-called isotachophoresis method allows for improved equilibrium binding and thus lowers the detection limit up to 400 times [93]. Pre-amplification is another excellent technique for increasing sensitivity. Amplifying DNA/RNA targeted samples by PCR prior to the lateral flow assay process can significantly boost lateral flow assay sensitivity up to RT-PCR's sensitivity level [94]. However, the PCR amplification technique requires expensive instruments and well-trained personnel. Although sample enrichment methods can help increase sensitivity by ten to hundreds of times (even reaching ultrasensitivity), these methods still require additional equipment, extra preparation steps, or prolong the testing period, making it difficult for them to use for POC testing.

\subsection{Signal Enhancement}

Signal enhancement for lateral flow assays involves either the development of a new optical reporter system or utilizing an external signal reader to amplify the signal intensity and contrast. AuNPs with a nominal size around $20-40 \mathrm{~nm}$ have been widely used for conventional lateral flow assays. So far, most LFIAs for COVID-19 detection were developed using traditional AuNPs, but their sensitivities were not very high. In recent years, fluorescent nanoparticles have been increasingly applied in disease diagnosis and are promising alternative reporters, as their unique chemical and optical properties mean that they have the potential to enhance the sensitivity of lateral flow assays. Many fluorescence nanoparticles were utilized for SARS-CoV-2 detection, including QDs [95], FNDs [96], selenium nanoparticles [65,97], up-converting phosphor particles [98], lanthanide-doped nanoparticles [64], and aggregation-induced emission (AIE) nanoparticles [66].

\subsubsection{Gold Nanoparticles (AuNPs)}

Modifying the size or structure of conventionally used AuNPs can achieve higher sensitivity. The optical signal of gold nanoparticles in colorimetric lateral flow assay can be amplified through the deposition of silver, gold nanoparticles, and enzymes [90]. For example, Liu et al. used AuNPs-decorated silica nanorods as visual reporters for the detection of rabbit IgG [99]. The lateral flow assay strip had a detection limit that was 50 times lower than conventional AuNPs. In another study, Liu et al. coated AuNPs in polystyrene latex microspheres (PS) to increase the sensitivity for determining influenza virus H3 subtype [100]. Along with the sandwich format, the use of AuNPs-PS as a reporter for influenza virus detection can achieve 64 times higher sensitivity than that of $10 \mathrm{~nm}$ AuNPs. In addition to changing AuNPs' size and structure, a photon-counting approach is another method of enhancing lateral flow assay's sensitivity and detection limit. In a recent study, Peng et al. utilized a simple laser optical system to quantify SARS-CoV-2 IgG/IgM antibodies on a traditional AuNPs-based lateral flow assay with higher sensitivity, as shown in Figure 6 [58]. The LFIA strip was generally constructed with an IgG test line, an IgM test line, and a control line. Rabbit IgG-conjugated AuNPs and SARS-CoV-2 spike protein-coated AuNPs were used as reporters. For quantification, a $532 \mathrm{~nm}$ laser was directed at the LFIA strip and subsequently captured by a photon detector through a 
two-lens imaging system. This laser readout system can provide a rapid quantification on a conventional LFIA with a sensitivity of $0.1 \mathrm{ng} \operatorname{IgG~mL}{ }^{-1}$ and a detection limit of approximately $4 \times 10^{8} \mathrm{IgG}$ molecules.
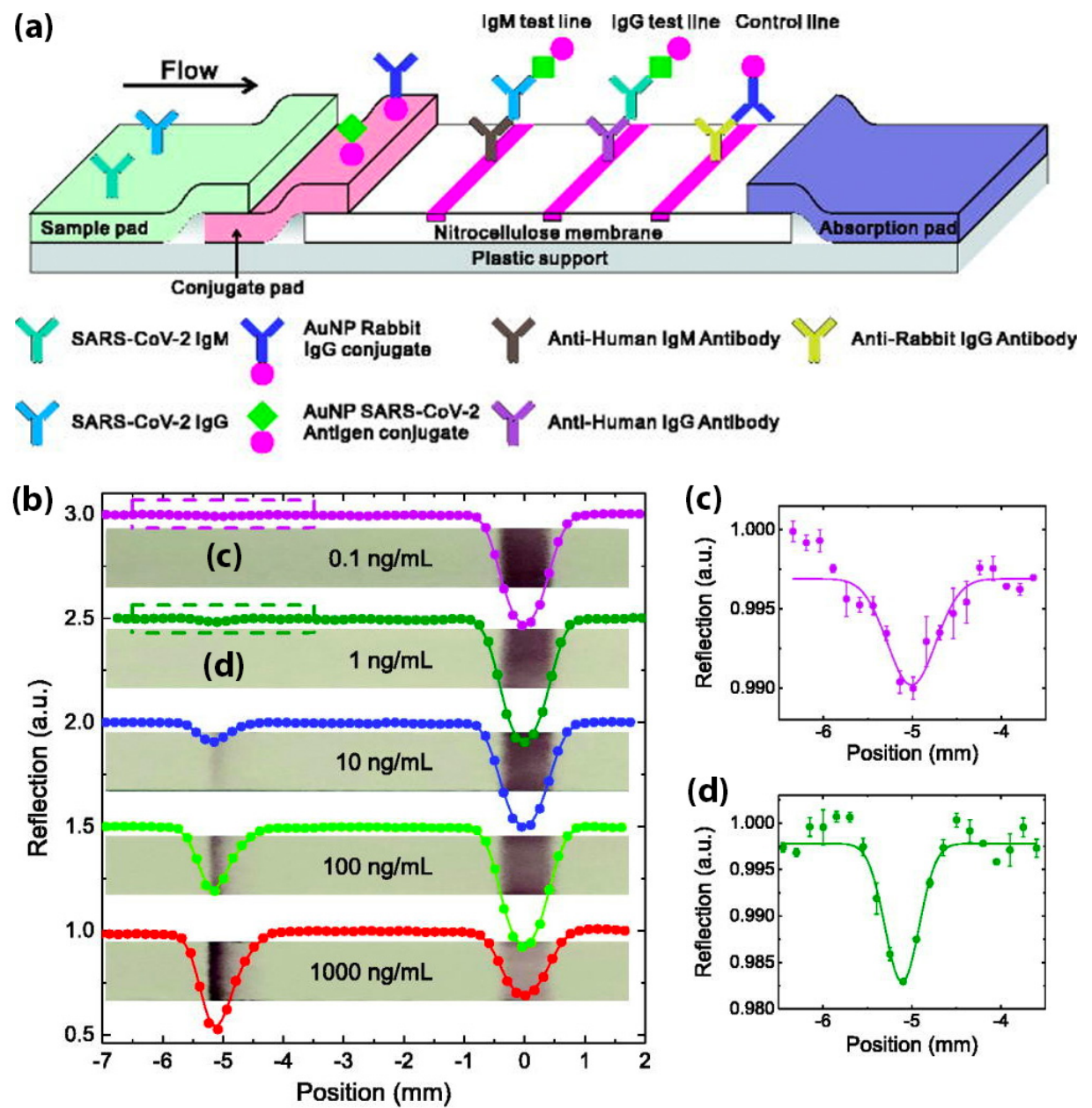

Figure 6. (a) AuNPs-based LFIA device for the detection of SARS-CoV-2 antibodies. (b) IgG concentrations on LFIA test strip from 1000 to $0.1 \mathrm{ng} / \mathrm{mL}$, bottom to top. Dips at $\approx-5 \mathrm{~mm}$ correspond to the IgG test lines and at $\approx 0 \mathrm{~mm}$ correspond to the control lines. (c,d) expansion spectra of $0.1 \mathrm{ng} / \mathrm{mL}$ and $1 \mathrm{ng} / \mathrm{mL}$ and Gaussian fittings (solid line). Reprinted from [58], with the permission of AIP Publishing.

\subsubsection{Quantum Dots (QDs)}

Quantum Dots (QDs), also known as fluorescent semiconductor nanocrystals, can be a potential avenue for creating a highly sensitive lateral flow assay due to their high brightness, non-photobleaching, chemical and thermal stability, and ease of surface modification [101,102]. Their size of QD ranges from 1 to $10 \mathrm{~nm}$. As a result, they are welldispersed in water and can also combine with biomolecules. However, the small size of QD has limitations for the large-scale production of QD-based lateral flow assay [63].

Many QD-based LFIAs have been developed to achieve ultrasensitive detection [62,103-105]. In a recent study, Wang et al. reported a dual-mode LFIA for SARS-CoV-2 IgM/IgG detection based on QD nanobeads (Figure 7) [63]. Using the polyethyleneimine (PEI)-mediated electrostatic absorption method, QD nanobeads were composed of AuNPs $(\approx 4 \mathrm{~nm})$ and $\mathrm{CdSe} / \mathrm{ZnS}-\mathrm{MPA}$ QD layers outside the core of the $\mathrm{SiO}_{2}$ nanospheres $(\approx 200 \mathrm{~nm})$. Then, the $\mathrm{SiO}_{2} @ \mathrm{Au} @ Q D$ nanobeads were conjugated with SARS-CoV-2 $\mathrm{S}$ protein to create a highly sensitive LFIA. The tests were carried out on 16 positive COVID-19 serum samples and 41 serum samples from other viral respiratory diseases. Through colorimetric and fluores- 
cent signals, the QD nanobead-based LFIA achieved 100\% sensitivity and 100\% specificity for SARS-CoV-2 IgG detection. In another report, Liu et al. proposed a QD-based LFIA for SARS-CoV-2 detection method with $99 \%$ sensitivity and $100 \%$ specificity compared to the nucleic acid test [61]. Moreover, with QDs as a reporter, this LFIA utilized a portable fluorescent smartphone system, which is promising for ultrasensitive and highly specific POC testing.
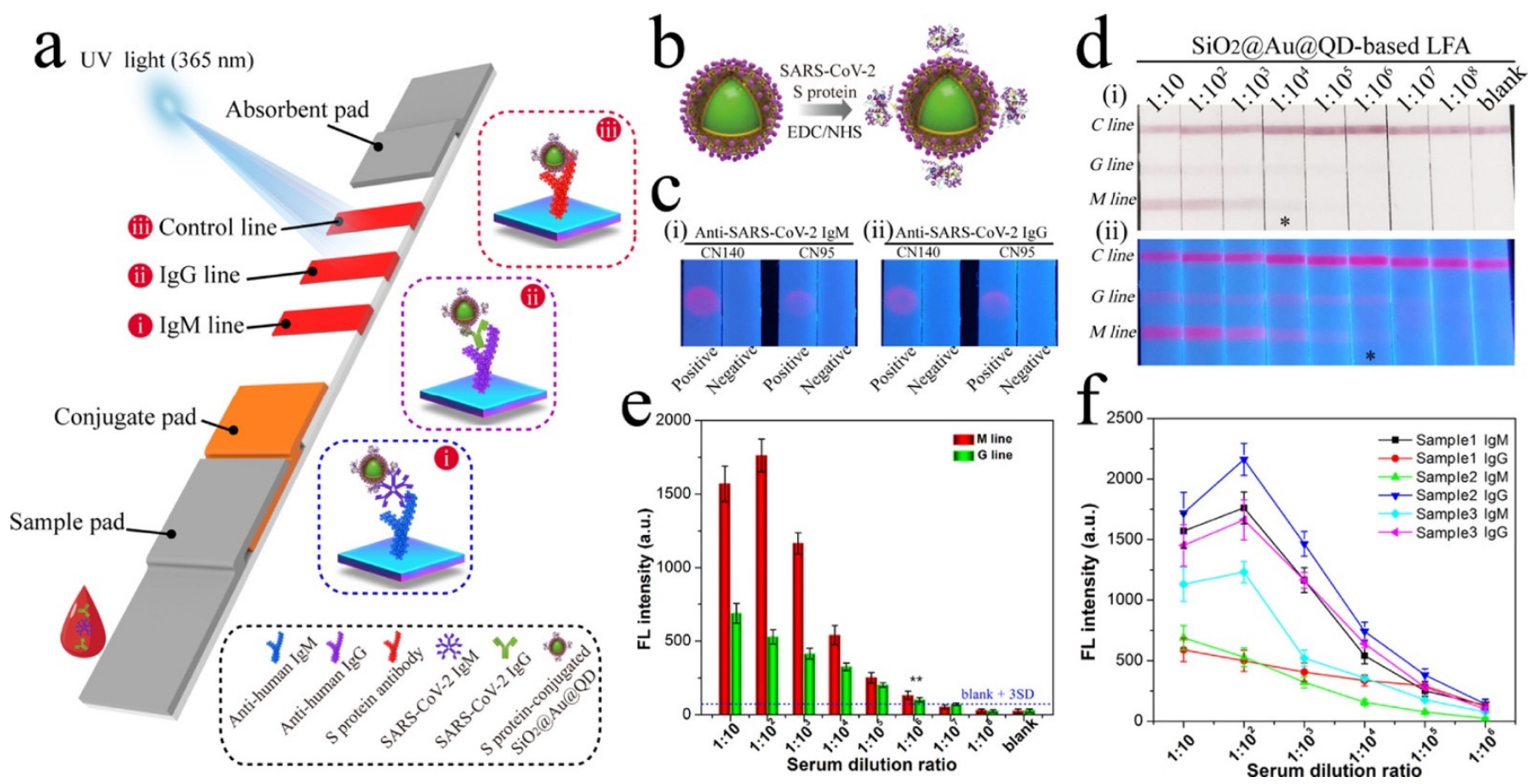

Figure 7. (a) A dual-mode $\mathrm{SiO}_{2} @ A u @ Q D-b a s e d ~ L F I A$ biosensor for SARS-CoV-2 detection. (b) S protein-conjugated $\mathrm{SiO}_{2} @ \mathrm{Au} @ Q D s$ were prepared by EDC/NHS coupling. (c) Optimization of LFIA NC membrane. (d) Photographs (i) and fluorescence images (ii) of the dual-mode LFIA for SARS-CoV-2-positive serum samples with different dilutions. (e) Corresponding fluorescence intensities of two test lines of the dual-mode LFIA. (f) Relationship of fluorescence intensity of test lines for three different positive serum samples with different dilutions. Preprinted with permission from [63]. Copyright ( 2020, American Chemical Society.

\subsubsection{Fluorescent Nanodiamonds (FNDs)}

Fluorescent nanodiamond (FND) is highly biocompatible, low in toxicity, and have physiochemical inert nanoparticles [106-110]. In addition, FNDs are an excellent alternative for LFIA reporters due to the high density of negatively charged nitrogen-vacancy $\left(\mathrm{NV}^{-}\right)$centers that act as built-in fluorophores [111]. The $\mathrm{NV}^{-}$center is a six-electron system with two unpaired spins at ground state [112,113]. This color center is red fluorescent, photostable, and the spin states can be optically polarized through electronic excitation with green-orange light, resulting in a high-intensity fluorescence emission that reaches its maximum after excitation. However, under an external magnetic field, a decrease in fluorescence intensity is observed. This unique feature can be utilized as an effective method to detect FND by magnetic modulation of $\mathrm{NV}^{-}$centers under the interference of high background conditions [111]. Moreover, the surfaces of FND can be chemically modified to contain emitters buried deep in a chemically inert matrix, so the optical properties are hardly affected by environmental changes (such as viscosity, $\mathrm{pH}$, and ion concentration). Therefore, FND has been studied for biological applications such as nanoscale thermometry, drug delivery, and cell tracking [111,114-119], and it is a promising reporter for LFIA.

In a study, Feuerstein et al. used different sizes of FNDs (200, 400, and $800 \mathrm{~nm}$ ) to develop a lateral flow technology for the detection of Ebola virus [120]. FND was conjugated with anti-Ebola virus glycoprotein monoclonal antibodies for a sandwich-type 
lateral flow test. The near-infrared emission can be measured by an in vivo imaging system or an optoelectronic device (OED). The $200 \mathrm{~nm}$ FNDs had the highest sensitivity among the test samples measured by the OED. Moreover, the OED provided quantitative data in less than one minute and was estimated to measure up to 1440 tests each day on a single OED setting. Furthermore, Miller et al. reported a spin-enhanced lateral flow system by using a microwave field [121]. The fluorescent intensity can be modulated to separate the autofluorescence background signal. The FND-based lateral flow assay can provide $10^{5}$ times higher sensitivity than conventional AuNPs. Moreover, after the signal preamplification process, the test can detect a single copy of HIV-1 RNA. The method also highlights the potential of FNDs as reporters for early disease diagnosis.

More recently, Hui et al. utilized the unique magneto-optical properties of the $\mathrm{NV}^{-}$ centers in to develop a platform called Spin-Enhanced Lateral Flow Immunoassay (SELFIA) for ultrasensitive biomedical analysis (Figure 8) [96]. The SELFIA platform promises to effectively remove the conventional LFIA's background fluorescence signals and obtain a lower detection limit compared to colloidal gold particles of similar size. In their work, the LFIA strip is generally made of NC membrane, which can interfere with fluorescent detection as a result of the photoexcitation process. Using FND as a reporter, SELFIA can offer background-free detection through magnetic modulation. The $100 \mathrm{~nm}$ FNDs were coated with biotinylated bovine serum albumin (B-BSA) and captured by neutravidin after the LFIA assays were processed. In addition, human chorionic gonadotropin (hCG)- $\beta$ antibodies were coated with FND to detect hCG in a sandwich SELFIA. The FND on the NC membrane were detected at a particle density of $0.04 \mathrm{ng} \mathrm{mm}^{-2}$ (approximately $2 \times 10^{4}$ particles per $\mathrm{mm}^{2}$ ). Moreover, by using larger size FND, the detection limit was reduced to 100 particles per $\mathrm{mm}^{2}$. The device offered ultrasensitive background-free detection using FND as a reporter, and it shows the promise of FND-based LFIA for detecting various viral diseases, including COVID-19. 
(a)
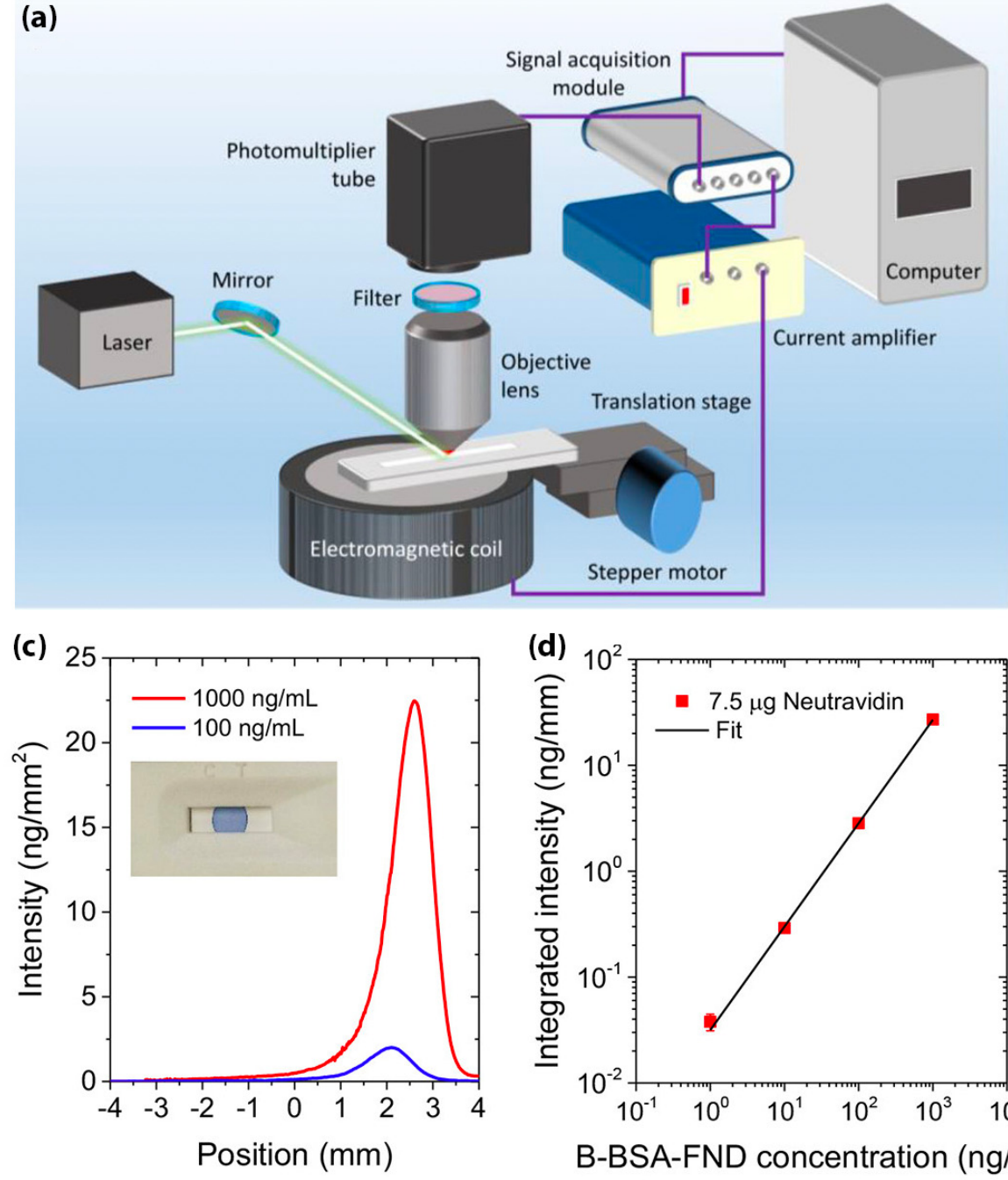

(d)

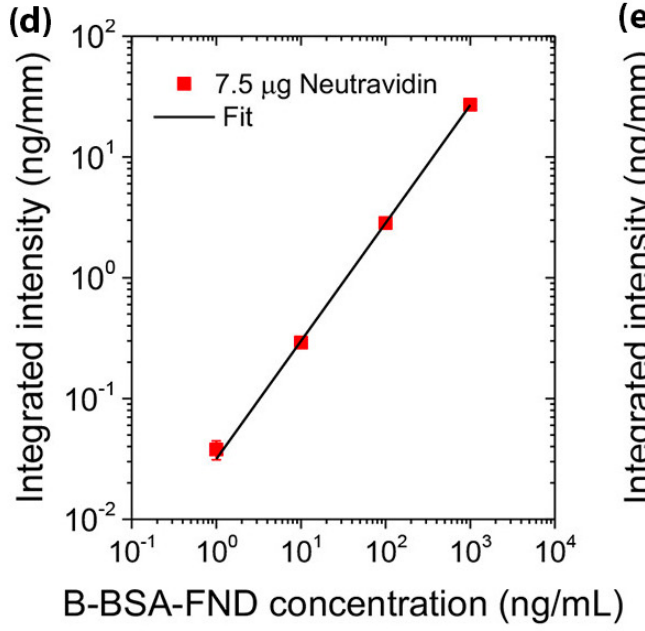

(b)

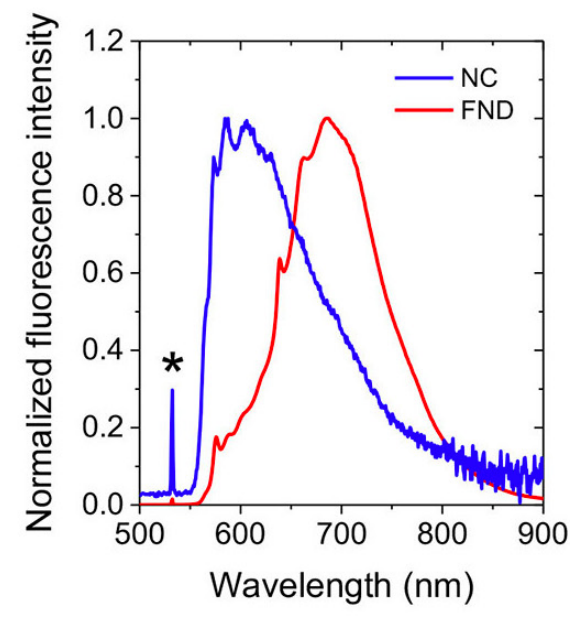

(e)

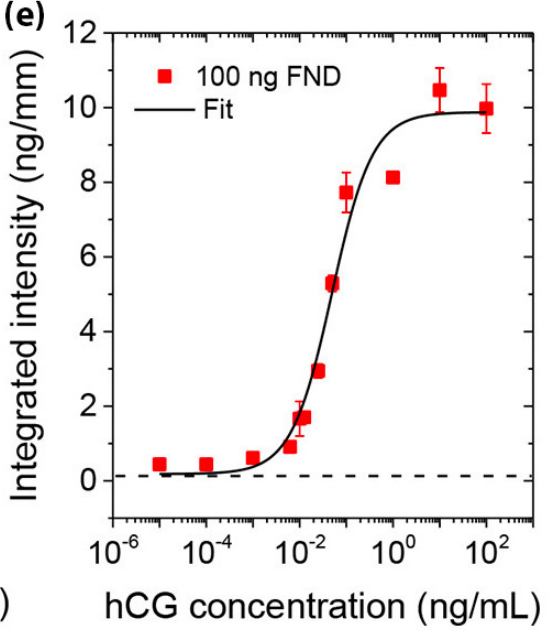

Figure 8. (a) Spin-enhanced lateral flow immunoassay (SELFIA) device. (b) Emission spectra of NC membrane and FNDs excited by a $532 \mathrm{~nm}$ laser. The asterisk $\left({ }^{*}\right)$ denotes unfiltered scattered laser light. (c) B-BSA-FNDs captured by the neutravidin bands formed on NC strips. The B-BSA-FND solution flowed from right to left. Inset: photo of a $1.5 \mu \mathrm{L}$ trypan blue solution deposited on an NC strip to assist the assessment of the spot size of neutravidin. (d) Measured fluorescence intensities of B-BSA-FNDs captured by NC-bound neutravidin as a function of the B-BSA-FND concentration. (e) Sandwich SELFIA of hCG with anti- $\beta$ hCG-coated FNDs and anti- $\beta$ hCG deposited on NC strips. Reprinted with permission from [96]. Copyright (C) 2020, American Chemical Society.

Compared to AuNPs and QDs, there are only a few studies that have utilized FND as a reporter for LFIA devices so far. Further investigation of FND-based LFIA tests is necessary to determine its feasibility as an ultrasensitive and highly accurate method of disease detection. However, the development of new reporters has helped transform LFIA into a rapid and simple test without having to modify assay formats or steps.

\subsection{Method for Improving Specificity}

\subsubsection{Phage Display Technique for SARS-CoV-2 Antibody Selection}

Specificity is another important factor that directly affects the accuracy of the lateral flow assay. Lateral flow assays for COVID-19 detection may be inaccurate due to the cross-reactivity of the SARS-CoV-2 virus with other coronaviruses. The cross-reactivity can reduce the specificity of the test, thus generating false positive results. To overcome this issue, phage display can be used to select SARS-CoV-2 antibodies with the strongest affinity. The phage display technique is a powerful method within the field of molecular 
biology that was awarded the 2018 Nobel Prize in Chemistry and has been widely used for the selection of antibodies, peptides, and disease-specific antigens [122]. In phage display, an exogenous DNA fragment encoding a protein of interest is inserted into a phage coat protein gene on the exposed surface, which is then capable of interacting with various external target molecules. This phenotype-genotype interaction enables researchers to isolate target-specific ligands [123].

Phage display has been used to develop a variety of diagnostics and treatments, as well as in the investigation of antibody-antigen interactions, and epitope mapping for SARS-CoV-2 [122,124-126]. Using the phage display method, researchers are able to isolate SARS-CoV-2 monoclonal chicken egg yolk IgY antibodies (Figure 9) [127]. Compared to the commonly used IgG antibody for LFIA, the IgY antibody has a stronger binding affinity to the SARS-CoV-2 spike antigen. In addition, the production of IgY by phage display is cost-effective and profitable, since antibodies can be harvested largely from egg yolks. Moreover, IgY has been demonstrated to be heat resistant at a temperature range of 30-70 ${ }^{\circ} \mathrm{C}$, stable at $\mathrm{pH} 3-11$, and able to be stored for 6 months at room temperature or up to 10 years at $4{ }^{\circ} \mathrm{C}$ [128]. Therefore, due to its unique properties, IgY is a good candidate for LFIA and other diagnostics and therapeutics.

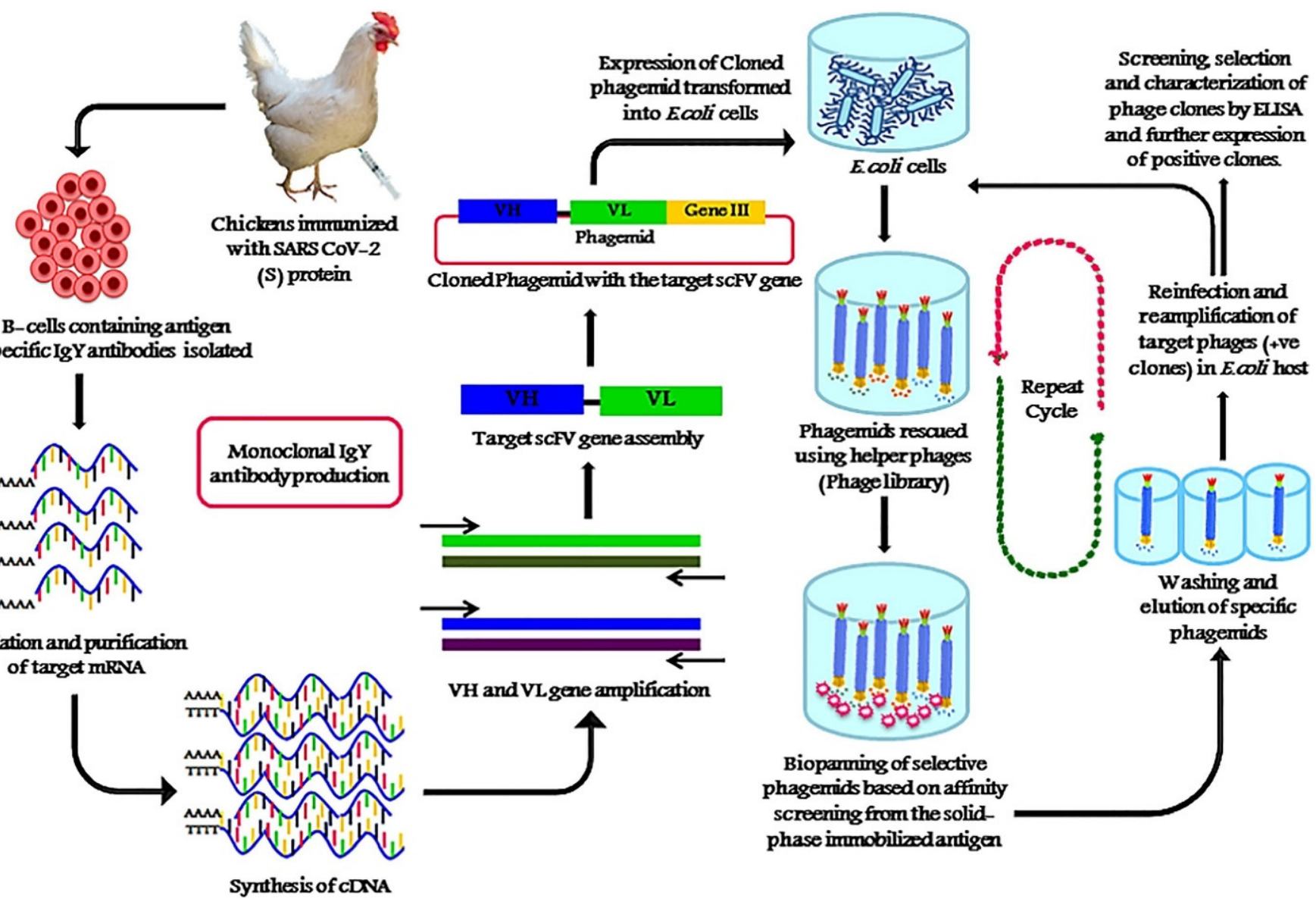

Figure 9. Production of anti-SARS-CoV-2 monoclonal scFv IgY antibodies against the spike protein (S) of SARS-CoV-2 antigen using phage display technology. Reprinted from [127]. Copyright 2020, with permission from Elsevier.

\subsubsection{CRISPR/Cas-Mediated Lateral Flow Nucleic Acid Assay}

Clustered regularly interspaced short palindromic repeats (CRISPR) and CRISPRrelated (Cas) have been used in many applications, including diagnostic, biosensing, imaging and led to the 2020 Nobel Prize in Chemistry. Therefore, many studies have applied CRISPR/Cas in COVID-19 detection $[14,129,130]$. In conjunction with lateral flow 
assay, Wang et al. developed a method called CRISPR/Cas-mediated lateral flow nucleic acid assay (CASLFA) using lateral flow assay incorporated with a Cas9 effector [131]. Within $1 \mathrm{~h}$, the CASLFA can achieve a low detection limit (near to PCR level) with 100\% specificity, indicating that CASLFA is a good candidate for further POC testing. However, more studies are required to optimize the CRISPR/Cas recognition step and assay time.

\subsubsection{Minimizing Non-Specific Binding}

Specificity can also be enhanced by minimizing non-specific binding and non-specific interactions of the reporter to the targeted analytes and the membrane [88]. To reduce nonspecific binding, a pre-filtration or centrifugation step can be applied to remove undesirable substances in the whole blood [132]. Optimizing reporter size and concentration and blocking the conjugated reporter by surface modification can also help minimize nonspecific binding. Several proteins, sugars, and PEG polymer can be a surface coating or chemically conjugated to the reporter to enhance stability [90]. In addition, the running buffer also strongly affects the specificity of tests. Surfactants can help reduce non-specific binding; however, in high concentrations, it also reduces specific binding [88]. The $\mathrm{pH}$ and ionic strength of the buffer solution also need to be considered when optimizing the running buffer. A summary of methods for enhancing the sensitivity and specificity of lateral flow assays can be found in Table 3 .

Table 3. Methods for enhancing sensitivity and specificity of lateral flow technologies.

\begin{tabular}{|c|c|c|}
\hline & Strategy & Method \\
\hline \multirow{3}{*}{ 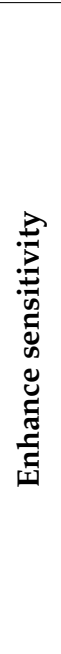 } & Sample enrichment & $\begin{array}{l}\text { Pre-concentration: } \\
\text { - } \quad \text { Filtration } \\
\text { - } \quad \text { Centrifugation } \\
\text { - } \quad \text { Magnetic pre-concentration } \\
\text { - } \quad \text { Applying electric field } \\
\text { PCR } \text { pre-amnlification of nucleic acid analvtes }\end{array}$ \\
\hline & \multirow[b]{2}{*}{ Signal enhancement } & $\begin{array}{l}\text { Nanomaterials as reporter: } \\
\text { - Modified AuNPs, quantum dots, fluorescent nanodiamond, selenium } \\
\text { NPs, up-converting phosphor particles, lanthanide-doped NPs, } \\
\text { aggregation-induced emission (AIE) NPs }\end{array}$ \\
\hline & & $\begin{array}{l}\text { External reader: } \\
\text { - } \quad \text { Optical reader } \\
\text { - } \quad \text { Fluorescence } \\
\text { - } \quad \text { Chemiluminescence } \\
\text { - } \quad \text { Raman }\end{array}$ \\
\hline \multirow{2}{*}{ 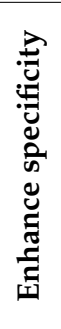 } & Maximizing specific binding & $\begin{array}{l}\text { High-affinity molecules } \\
\text { Phage display technology for antibody selection } \\
\text { CRISPR/Cas-mediated lateral flow assays }\end{array}$ \\
\hline & Minimizing non-specific binding & $\begin{array}{l}\text { Pre-filtration or centrifugation } \\
\text { Optimizing size and concentration } \\
\text { Surface modification with proteins, sugars, PEG. } \\
\text { Optimizing running buffer } \\
\text { Membrane blocking }\end{array}$ \\
\hline
\end{tabular}

\section{Role of Smartphones in Disease Control and Surveillance during the COVID-19 Pandemic}

Recent smartphone generations are equipped with a powerful internal camera that can assist in POC testing when proper design software is implemented. Several applications that can assist in immunochromatography have been developed. These programs are capable of processing images to achieve quantitative analysis without any external equipment [33]. However, these methods may provide low reproducible results due to the interfering of light, camera position, or even the steadiness of the camera operator. For this 
issue, AI could be an excellent solution. Recently, Mendels et al. applied AI to improve test result interpretations of conventional LFIA assay for COVID-19 detection [133]. By developing their smartphone app, xRCovid, they largely removed human errors using machine learning. Finally, they claimed that this app achieved $99.3 \%$ precision compared to eye reading and is therefore beneficial for POC testing in the future. In addition, smartphones can be used for fluorescent reporter-based lateral flow assay, which usually provides higher sensitivity testing. By using a special lens or accessories, the device is portable, and can be used at the patients' side for providing high accuracy and performance. Recently, Liu et al. reported a portable fluorescence smartphone system for ultrasensitive detection of IgM/IgG to SARS-CoV-2 [61]. Among 100 COVID-19 positive samples and 450 healthy blood samples, the QD-based LFIA for the detection of SARS-CoV-2 IgM and IgG antibodies can achieve $99 \%$ sensitivity with only $0.22 \%$ cross-reactive results. Moreover, AI has also been integrated with LFIA. The LooK SPOT AI COVID-19 Antigen Rapid Test system (Laipac Technology Inc., Canada) was approved by European CE-IVD as a LFIA diagnostic device that targets $\mathrm{N}$ protein antigen in nasal swabs [134]. Smartphone-AI-aided detection can quantitatively detect the signal intensity at a low level for reducing misdiagnosis. Test results can be provided in 5-8 min with a high sensitivity of $97.4 \%$ and a specificity of $98.3 \%$. Figure 10 shows a schematic diagram of a portable AI-aided smartphone LFIA system for COVID-19 detection based upon the above-mentioned research work $[61,133,134]$.

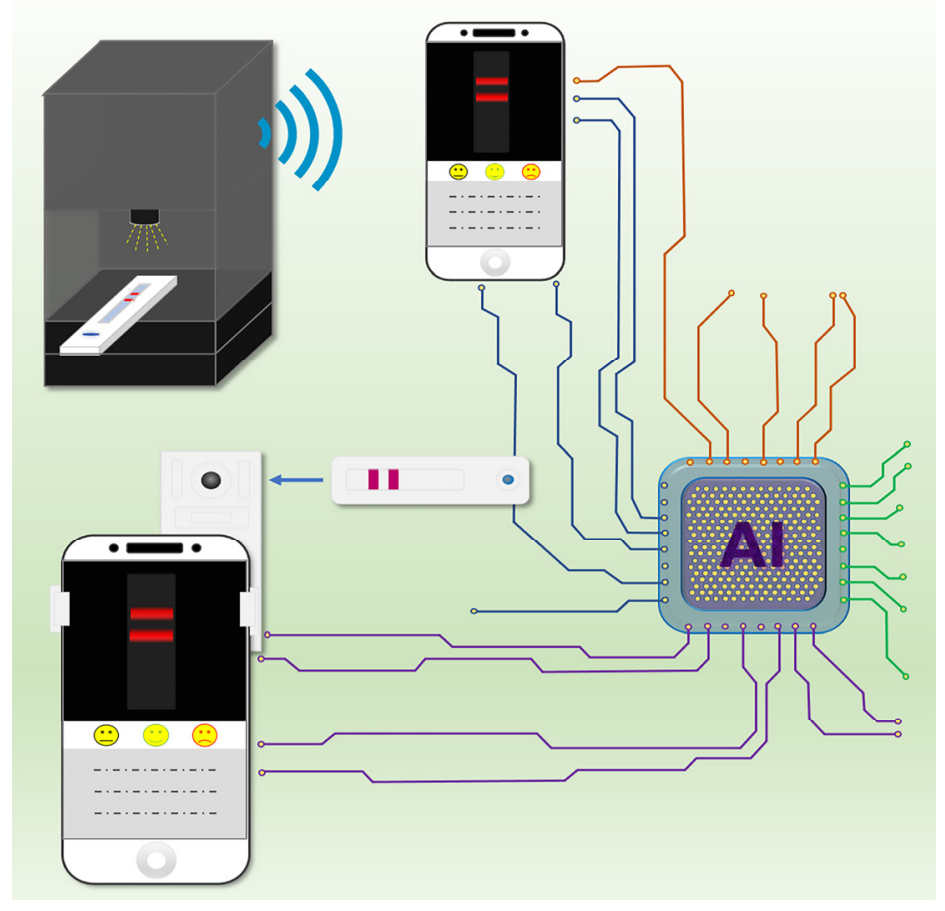

Figure 10. Schematic diagram of a portable AI-aided smartphone LFIA system for COVID-19 detection $[61,133,134]$.

\section{Conclusions}

Lateral flow technologies developed during the COVID-19 pandemic are portable, fast-acting, inexpensive, and easy to use, and therefore, they are becoming one of the most suitable techniques to practice POC testing. A comparison of recent COVID-19 detection methods has been described in Figure 11. Although false negative and false positive issues limit their clinical use, researchers around the world have worked together to improve the efficiency and accuracy of lateral flow tests in the hopes of creating a universal test for COVID-19. This article has provided an overview of lateral flow assay testing developments as well as detailed information about how their sensitivity and specificity can be improved. So far, many reports mentioned in this review were able to obtain comparable sensitivity 
and specificity testing at similar ELISA or even RT-PCR levels. However, most of these methods require the use of an external signal reader instrument. To overcome this issue, smartphone and AI integration can be mobilized in future POC testing.

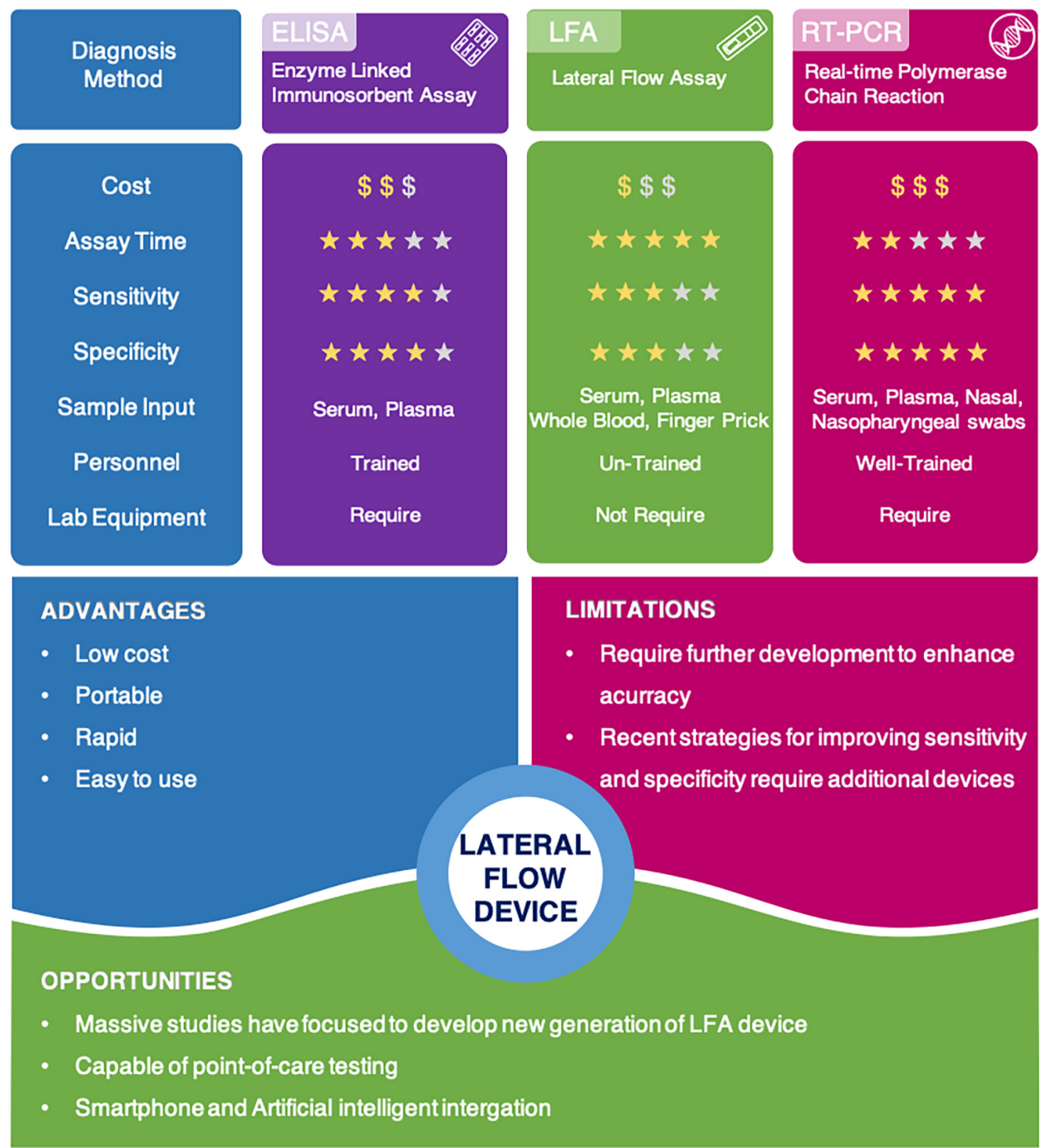

Figure 11. Comparison of current COVID-19 detection methods and advantages, limitations, and opportunities of lateral flow technologies.

\section{Future Perspectives}

Nowadays, smartphones are indispensable personal devices. As a result of their connectivity, Global Positioning System (GPS), and computational capabilities, smartphones can provide significant improvements to contact tracking and tracing, patient isolation, and monitoring for disease control and surveillance during a pandemic. Smartphones have been used as infectious diseases monitoring tools by identifying individuals who have been in contact with a patient. Finally, AI can also be used for analyzing every day test results, which is something that has been demonstrated to be a sufficient strategy for disease surveillance through accurately identifying infected individuals. In addition to lateral flow assays, many other diagnostic methods have been incorporated with smartphones and AI for POC testing, such as RT-PCR, CRISPR/Cas, chest computed tomography and 
paper microfluidic device $[39,135-140]$. These developments have revolutionized disease diagnosis by offering an approach to POC testing that is fast, accurate, cheap, and easy to use.

Author Contributions: Conceptualization, W.W.-W.H., D.M.P., H.-C.C., C.-K.L., and W.-H.C.; investigation, W.W.-W.H. and T.-N.L.; writing-original draft preparation, W.W.-W.H. and T.-N.L.; writing-review and editing, W.W.-W.H., T.-N.L., D.M.P., H.-H.K., H.-C.C., C.-C.L., N.S., C.-K.L., and W.-H.C.; visualization, T.-N.L.; supervision, W.W.-W.H., H.-C.C., C.-K.L., and W.-H.C.; project administration, W.W.-W.H. All authors have read and agreed to the published version of the manuscript.

Funding: This study was supported by Project \#110-2222-E-011-004 (Ministry of Science and Technology, Taiwan).

Institutional Review Board Statement: Not applicable.

Informed Consent Statement: Not applicable.

Conflicts of Interest: The authors declare no conflict of interest.

\section{References}

1. World Health Organization. Coronavirus Disease (COVID-19). 2020. Available online: https://covid19.who.int (accessed on 20 July 2021).

2. Liu, K.; Chen, Y.; Lin, R.; Han, K. Clinical features of COVID-19 in elderly patients: A comparison with young and middle-aged patients. J. Infect. 2020, 80, e14-e18. [CrossRef] [PubMed]

3. Wang, L.; Wang, Y.; Ye, D.; Liu, Q. Review of the 2019 novel coronavirus (SARS-CoV-2) based on current evidence. Int. J. Antimicrob. Agents 2020, 55, 105948. [CrossRef] [PubMed]

4. Wu, Z.; McGoogan, J.M. Characteristics of and important lessons from the coronavirus disease 2019 (COVID-19) outbreak in China: Summary of a report of 72,314 cases from the Chinese Center for Disease Control and Prevention. JAMA 2020, 323, 1239-1242. [CrossRef] [PubMed]

5. Mizumoto, K.; Kagaya, K.; Zarebski, A.; Chowell, G. Estimating the asymptomatic proportion of coronavirus disease 2019 (COVID-19) cases on board the Diamond Princess cruise ship, Yokohama, Japan, 2020. Eurosurveillance 2020, 25, 2000180. [CrossRef] [PubMed]

6. Ing, A.J.; Cocks, C.; Green, J.P. COVID-19: In the footsteps of Ernest Shackleton. Thorax 2020, 75, 693-694. [CrossRef] [PubMed]

7. Drain, P.K.; Hyle, E.P.; Noubary, F.; Freedberg, K.A.; Wilson, D.; Bishai, W.R.; Rodriguez, W.; Bassett, I.V. Diagnostic point-of-care tests in resource-limited settings. Lancet Infect. Dis. 2014, 14, 239-249. [CrossRef]

8. Gubala, V.; Harris, L.F.; Ricco, A.J.; Tan, M.X.; Williams, D.E. Point of care diagnostics: Status and future. Anal. Chem. 2012, 84, 487-515. [CrossRef] [PubMed]

9. Udugama, B.; Kadhiresan, P.; Kozlowski, H.N.; Malekjahani, A.; Osborne, M.; Li, V.Y.; Chen, H.; Mubareka, S.; Gubbay, J.B.; Chan, W.C. Diagnosing COVID-19: The disease and tools for detection. ACS Nano 2020, 14, 3822-3835. [CrossRef] [PubMed]

10. Cui, F.; Zhou, H.S. Diagnostic methods and potential portable biosensors for coronavirus disease 2019. Biosens. Bioelectron. 2020, 165, 112349. [CrossRef]

11. Pokhrel, P.; Hu, C.; Mao, H. Detecting the coronavirus (COVID-19). ACS Sens. 2020, 5, 2283-2296. [CrossRef]

12. Weiss, C.; Carriere, M.; Fusco, L.; Capua, I.; Regla-Nava, J.A.; Pasquali, M.; Scott, J.A.; Vitale, F.; Unal, M.A.; Mattevi, C. Toward nanotechnology-enabled approaches against the COVID-19 pandemic. ACS Nano 2020, 14, 6383-6406. [CrossRef] [PubMed]

13. Eftekhari, A.; Alipour, M.; Chodari, L.; Maleki Dizaj, S.; Ardalan, M.R.; Samiei, M.; Sharifi, S.; Zununi Vahed, S.; Huseynova, I.; Khalilov, R. A comprehensive review of detection methods for SARS-CoV-2. Microorganisms 2021, 9, 232. [CrossRef] [PubMed]

14. Nguyen, N.N.; McCarthy, C.; Lantigua, D.; Camci-Unal, G. Development of diagnostic tests for detection of SARS-CoV-2. Diagnostics 2020, 10, 905. [CrossRef] [PubMed]

15. Carter, L.J.; Garner, L.V.; Smoot, J.W.; Li, Y.; Zhou, Q.; Saveson, C.J.; Sasso, J.M.; Gregg, A.C.; Soares, D.J.; Beskid, T.R.; et al. Assay techniques and test development for COVID-19 diagnosis. ACS Cent. Sci. 2020, 6, 591-605. [CrossRef]

16. De Vries, R.; Vigeveno, R.M.; Mulder, S.; Farzan, N.; Vintges, D.R.; Goeman, J.J.; Bruisten, S.; van den Corput, B.; Geelhoed, J.J.M.; Visser, L.G.; et al. Ruling out SARS-CoV-2 infection using exhaled breath analysis by electronic nose in a public health setting. medRxiv 2021. [CrossRef]

17. Antiochia, R. Developments in biosensors for CoV detection and future trends. Biosens. Bioelectron. 2021, 173, 112777. [CrossRef] [PubMed]

18. Shen, M.; Zhou, Y.; Ye, J.; Al-Maskri, A.A.A.; Kang, Y.; Zeng, S.; Cai, S. Recent advances and perspectives of nucleic acid detection for coronavirus. J. Pharm. Anal. 2020, 10, 97-101. [CrossRef] [PubMed]

19. Waggoner, J.J.; Stittleburg, V.; Pond, R.; Saklawi, Y.; Sahoo, M.K.; Babiker, A.; Hussaini, L.; Kraft, C.S.; Pinsky, B.A.; Anderson, E.J. Triplex real-time RT-PCR for severe acute respiratory syndrome coronavirus 2. Emerg. Infect. Dis. 2020, 26, 1633. [CrossRef] [PubMed] 
20. Kashir, J.; Yaqinuddin, A. Loop mediated isothermal amplification (LAMP) assays as a rapid diagnostic for COVID-19. Med. Hypotheses 2020, 141, 109786. [CrossRef] [PubMed]

21. Huang, W.E.; Lim, B.; Hsu, C.C.; Xiong, D.; Wu, W.; Yu, Y.; Jia, H.; Wang, Y.; Zeng, Y.; Ji, M. RT-LAMP for rapid diagnosis of coronavirus SARS-CoV-2. Microb. Biotechnol. 2020, 13, 950-961. [CrossRef]

22. Yu, L.; Wu, S.; Hao, X.; Dong, X.; Mao, L.; Pelechano, V.; Chen, W.-H.; Yin, X. Rapid detection of COVID-19 coronavirus using a reverse transcriptional loop-mediated isothermal amplification (RT-LAMP) diagnostic platform. Clin. Chem. 2020, 66, 975-977. [CrossRef] [PubMed]

23. Ackerman, C.M.; Myhrvold, C.; Thakku, S.G.; Freije, C.A.; Metsky, H.C.; Yang, D.K.; Ye, S.H.; Boehm, C.K.; Kosoko-Thoroddsen, T.-S.F.; Kehe, J.; et al. Massively multiplexed nucleic acid detection with Cas13. Nature 2020, 582, 277-282. [CrossRef] [PubMed]

24. Yelagandula, R.; Bykov, A.; Vogt, A.; Heinen, R.; Özkan, E.; Strobl, M.M.; Baar, J.C.; Uzunova, K.; Hajdusits, B.; Kordic, D.; et al. Multiplexed detection of SARS-CoV-2 and other respiratory infections in high throughput by SARSeq. Nat. Commun. 2021, 12, 3132. [CrossRef] [PubMed]

25. Antiochia, R. Paper-Based Biosensors: Frontiers in Point-of-Care Detection of COVID-19 Disease. Biosensors 2021, 11, 110. [CrossRef]

26. Nayak, S.; Blumenfeld, N.R.; Laksanasopin, T.; Sia, S.K. Point-of-care diagnostics: Recent developments in a connected age. Anal. Chem. 2017, 89, 102-123. [CrossRef]

27. Amanat, F.; Stadlbauer, D.; Strohmeier, S.; Nguyen, T.H.; Chromikova, V.; McMahon, M.; Jiang, K.; Arunkumar, G.A.; Jurczyszak, D.; Polanco, J. A serological assay to detect SARS-CoV-2 seroconversion in humans. Nat. Med. 2020, 26, 1033-1036. [CrossRef]

28. Adams, E.R.; Ainsworth, M.; Anand, R.; Andersson, M.I.; Auckland, K.; Baillie, J.K.; Barnes, E.; Beer, S.; Bell, J.I.; Berry, T. Antibody testing for COVID-19: A report from the National COVID Scientific Advisory Panel. Wellcome Open Res. 2020, 5. [CrossRef]

29. Wu, J.-L.; Tseng, W.-P.; Lin, C.-H.; Lee, T.-F.; Chung, M.-Y.; Huang, C.-H.; Chen, S.-Y.; Hsueh, P.-R.; Chen, S.-C. Four point-of-care lateral flow immunoassays for diagnosis of COVID-19 and for assessing dynamics of antibody responses to SARS-CoV-2. J. Infect. 2020, 81, 435-442. [CrossRef]

30. Xiang, J.; Yan, M.; Li, H.; Liu, T.; Lin, C.; Huang, S.; Shen, C. Evaluation of enzyme-linked immunoassay and colloidal gold-immunochromatographic assay kit for detection of novel coronavirus (SARS-CoV-2) causing an outbreak of pneumonia (COVID-19). medRxiv 2020. [CrossRef]

31. Smith, R.L.; Gibson, L.L.; Martinez, P.P.; Ke, R.; Mirza, A.; Conte, M.; Gallagher, N.; Conte, A.; Wang, L.; Fredrickson, R. Longitudinal assessment of diagnostic test performance over the course of acute SARS-CoV-2 infection. medRxiv 2021. [CrossRef]

32. Screaton, G.; Mongkolsapaya, J.; Yacoub, S.; Roberts, C. New insights into the immunopathology and control of dengue virus infection. Nat. Rev. Immunol. 2015, 15, 745-759. [CrossRef]

33. Andryukov, B.G. Six decades of lateral flow immunoassay: From determining metabolic markers to diagnosing COVID-19. AIMS Microbiol. 2020, 6, 280-304. [CrossRef]

34. Wild, D. The Immunoassay Handbook, 3rd ed.; Elsevier: New York, NY, USA, 2005; ISBN1 0080445268; ISBN2 9780080445267.

35. Urusov, A.E.; Zherdev, A.V.; Dzantiev, B.B. Towards lateral flow quantitative assays: Detection approaches. Biosensors $2019,9,89$. [CrossRef]

36. Cheng, C.-M. Small-Volume point-of-care analytical methods. Sci. Rep. 2020, 10, 14230. [CrossRef]

37. Koczula, K.M.; Gallotta, A. Lateral flow assays. Essays Biochem. 2016, 60, 111-120.

38. Saisin, L.; Amarit, R.; Somboonkaew, A.; Gajanandana, O.; Himananto, O.; Sutapun, B. Significant sensitivity improvement for camera-based lateral flow immunoassay readers. Sensors 2018, 18, 4026. [CrossRef]

39. Ruppert, C.; Phogat, N.; Laufer, S.; Kohl, M.; Deigner, H.-P. A smartphone readout system for gold nanoparticle-based lateral flow assays: Application to monitoring of digoxigenin. Microchim. Acta 2019, 186, 119. [CrossRef]

40. Posthuma-Trumpie, G.A.; Korf, J.; van Amerongen, A. Development of a competitive lateral flow immunoassay for progesterone: Influence of coating conjugates and buffer components. Anal. Bioanal. Chem. 2008, 392, 1215-1223. [CrossRef]

41. Chen, X.; Leng, Y.; Hao, L.; Duan, H.; Yuan, J.; Zhang, W.; Huang, X.; Xiong, Y. Self-assembled colloidal gold superparticles to enhance the sensitivity of lateral flow immunoassays with sandwich format. Theranostics 2020, 10, 3737. [CrossRef]

42. Jiang, X.; Lillehoj, P.B. Microneedle-based skin patch for blood-free rapid diagnostic testing. Microsyst. Nanoeng. 2020, 6, 96. [CrossRef]

43. Quesada-González, D.; Jairo, G.A.; Blake, R.C.; Blake, D.A.; Merkoçi, A. Uranium (VI) detection in groundwater using a gold nanoparticle/paper-based lateral flow device. Sci. Rep. 2018, 8, 16157. [CrossRef] [PubMed]

44. Srisrattakarn, A.; Tippayawat, P.; Chanawong, A.; Tavichakorntrakool, R.; Daduang, J.; Wonglakorn, L.; Lulitanond, A. Development of a Prototype Lateral Flow Immunoassay for Rapid Detection of Staphylococcal Protein A in Positive Blood Culture Samples. Diagnostics 2020, 10, 794. [CrossRef]

45. Zhang, Y.; Liu, X.; Wang, L.; Yang, H.; Zhang, X.; Zhu, C.; Wang, W.; Yan, L.; Li, B. Improvement in detection limit for lateral flow assay of biomacromolecules by test-zone pre-enrichment. Sci. Rep. 2020, 10, 9604. [CrossRef] [PubMed]

46. Tsai, T.-T.; Huang, T.-H.; Chen, C.-A.; Ho, N.Y.-J.; Chou, Y.-J.; Chen, C.-F. Development a stacking pad design for enhancing the sensitivity of lateral flow immunoassay. Sci. Rep. 2018, 8, 17319. [CrossRef] [PubMed]

47. Yu, S.; Nimse, S.B.; Kim, J.; Song, K.-S.; Kim, T. Development of a lateral flow strip membrane assay for rapid and sensitive detection of the SARS-CoV-2. Anal. Chem. 2020, 92, 14139-14144. [CrossRef] [PubMed] 
48. Zhu, X.; Wang, X.; Han, L.; Chen, T.; Wang, L.; Li, H.; Li, S.; He, L.; Fu, X.; Chen, S. Multiplex reverse transcription loop-mediated isothermal amplification combined with nanoparticle-based lateral flow biosensor for the diagnosis of COVID-19. Biosens. Bioelectron. 2020, 166, 112437. [CrossRef]

49. Wang, D.; He, S.; Wang, X.; Yan, Y.; Liu, J.; Wu, S.; Liu, S.; Lei, Y.; Chen, M.; Li, L. Rapid lateral flow immunoassay for the fluorescence detection of SARS-CoV-2 RNA. Nat. Biomed. Eng. 2020, 4, 1150-1158. [CrossRef] [PubMed]

50. Baker, A.N.; Richards, S.-J.; Guy, C.S.; Congdon, T.R.; Hasan, M.; Zwetsloot, A.J.; Gallo, A.; Lewandowski, J.R.; Stansfeld, P.J.; Straube, A. The SARS-CoV-2 spike protein binds sialic acids and enables rapid detection in a lateral flow point of care diagnostic device. ACS Cent. Sci. 2020, 6, 2046-2052. [CrossRef]

51. Diao, B.; Wen, K.; Chen, J.; Liu, Y.; Yuan, Z.; Han, C.; Chen, J.; Pan, Y.; Chen, L.; Dan, Y. Diagnosis of acute respiratory syndrome coronavirus 2 infection by detection of nucleocapsid protein. medRxiv 2020. [CrossRef]

52. Grant, B.D.; Anderson, C.E.; Williford, J.R.; Alonzo, L.F.; Glukhova, V.A.; Boyle, D.S.; Weigl, B.H.; Nichols, K.P. SARS-CoV-2 coronavirus nucleocapsid antigen-detecting half-strip lateral flow assay toward the development of point of care tests using commercially available reagents. Anal. Chem. 2020, 92, 11305-11309. [CrossRef]

53. Li, Z.; Yi, Y.; Luo, X.; Xiong, N.; Liu, Y.; Li, S.; Sun, R.; Wang, Y.; Hu, B.; Chen, W. Development and clinical application of a rapid IgM-IgG combined antibody test for SARS-CoV-2 infection diagnosis. J. Med. Virol. 2020, 92, 1518-1524. [CrossRef]

54. Wen, T.; Huang, C.; Shi, F.-J.; Zeng, X.-Y.; Lu, T.; Ding, S.-N.; Jiao, Y.-J. Development of a lateral flow immunoassay strip for rapid detection of IgG antibody against SARS-CoV-2 virus. Analyst 2020, 145, 5345-5352. [CrossRef]

55. Cavalera, S.; Colitti, B.; Rosati, S.; Ferrara, G.; Bertolotti, L.; Nogarol, C.; Guiotto, C.; Cagnazzo, C.; Denina, M.; Fagioli, F. A multi-target lateral flow immunoassay enabling the specific and sensitive detection of total antibodies to SARS-COV-2. Talanta 2021, 223, 121737. [CrossRef]

56. Roda, A.; Cavalera, S.; Di Nardo, F.; Calabria, D.; Rosati, S.; Simoni, P.; Colitti, B.; Baggiani, C.; Roda, M.; Anfossi, L. Dual lateral flow optical/chemiluminescence immunosensors for the rapid detection of salivary and serum IgA in patients with COVID-19 disease. Biosens. Bioelectron. 2021, 172, 112765. [CrossRef]

57. Huang, C.; Wen, T.; Shi, F.-J.; Zeng, X.-Y.; Jiao, Y.-J. Rapid detection of IgM antibodies against the SARS-CoV-2 virus via colloidal gold nanoparticle-based lateral-flow assay. ACS Omega 2020, 5, 12550-12556. [CrossRef]

58. Peng, T.; Liu, X.; Adams, L.G.; Agarwal, G.; Akey, B.; Cirillo, J.; Deckert, V.; Delfan, S.; Fry, E.; Han, Z. Enhancing sensitivity of lateral flow assay with application to SARS-CoV-2. Appl. Phys. Lett. 2020, 117, 120601. [CrossRef]

59. Peng, T.; Sui, Z.; Huang, Z.; Xie, J.; Wen, K.; Zhang, Y.; Huang, W.; Mi, W.; Peng, K.; Dai, X.; et al. Point-of-care test system for detection of immunoglobulin-G and -M against nucleocapsid protein and spike glycoprotein of SARS-CoV-2. Sens. Actuators $B$ Chem. 2021, 331, 129415. [CrossRef]

60. Drummer, H.E.; Van, H.; Klock, E.; Zheng, S.; Wei, Z.; Boo, I.; Center, R.J.; Li, F.; Bhat, P.; Ffrench, R. Dimeric IgA is a specific biomarker of recent SARS-CoV-2 infection. medRxiv 2021. [CrossRef]

61. Liu, B.; Li, J.; Tang, X.; Wu, Z.; Lu, J.; Liang, C.; Hou, S.; Zhang, L.; Li, T.; Zhao, W. Development of a quantum-dot lateral flow immunoassay strip based portable fluorescence smart-phone system for ultrasensitive detection of IgM/IgG to SARS-CoV-2. medRxiv 2020. [CrossRef]

62. Zhou, Y.; Chen, Y.; Liu, W.; Fang, H.; Li, X.; Hou, L.; Liu, Y.; Lai, W.; Huang, X.; Xiong, Y. Development of a rapid and sensitive quantum dot nanobead-based double-antigen sandwich lateral flow immunoassay and its clinical performance for the detection of SARS-CoV-2 total antibodies. Sens. Actuators B Chem. 2021, 343, 130139. [CrossRef]

63. Wang, C.; Yang, X.; Gu, B.; Liu, H.; Zhou, Z.; Shi, L.; Cheng, X.; Wang, S. Sensitive and simultaneous detection of SARSCoV-2-specific IgM/IgG using lateral flow immunoassay based on dual-mode quantum dot nanobeads. Anal. Chem. 2020, 92, 15542-15549. [CrossRef] [PubMed]

64. Chen, Z.; Zhang, Z.; Zhai, X.; Li, Y.; Lin, L.; Zhao, H.; Bian, L.; Li, P.; Yu, L.; Wu, Y. Rapid and sensitive detection of anti-SARSCoV-2 IgG, using lanthanide-doped nanoparticles-based lateral flow immunoassay. Anal. Chem. 2020, 92, 7226-7231. [CrossRef] [PubMed]

65. Wang, Z.-Z.; Zheng, Z.; Wang, X.-C.; Zheng, P.-M.; Cui, F.-C.; Zhou, Q.-W.; Hu, H.-Z.; Li, X.-Q.; Zhang, H.-L.; Wei, Y.-X.; et al. Rapid detection of anti-SARS-CoV-2 IgM and IgG using a selenium nanoparticle-based lateral flow immunoassay. Res. Sq. 2021. [CrossRef]

66. Chen, R.; Ren, C.; Liu, M.; Ge, X.; Qu, M.; Zhou, X.; Liang, M.; Liu, Y.; Li, F. Early Detection of SARS-CoV-2 Seroconversion in Humans with Aggregation-Induced Near-Infrared Emission Nanoparticle-Labeled Lateral Flow Immunoassay. ACS Nano 2021, 15, 8996-9004. [CrossRef]

67. Liu, H.; Dai, E.; Xiao, R.; Zhou, Z.; Zhang, M.; Bai, Z.; Shao, Y.; Qi, K.; Tu, J.; Wang, C. Development of a SERS-based lateral flow immunoassay for rapid and ultra-sensitive detection of anti-SARS-CoV-2 IgM/IgG in clinical samples. Sens. Actuators B Chem. 2021, 329, 129196. [CrossRef]

68. Zhao, J.; Yuan, Q.; Wang, H.; Liu, W.; Liao, X.; Su, Y.; Wang, X.; Yuan, J.; Li, T.; Li, J.; et al. Antibody Responses to SARS-CoV-2 in Patients with Novel Coronavirus Disease 2019. Clin. Infect. Dis. 2020, 71, 2027-2034. [CrossRef]

69. Okba, N.M.A.; Müller, M.A.; Li, W.; Wang, C.; GeurtsvanKessel, C.H.; Corman, V.M.; Lamers, M.M.; Sikkema, R.S.; de Bruin, E.; Chandler, F.D.; et al. Severe Acute Respiratory Syndrome Coronavirus 2-Specific Antibody Responses in Coronavirus Disease Patients. Emerg. Infect. Dis. 2020, 26, 1478-1488. [CrossRef] 
70. Stadlbauer, D.; Amanat, F.; Chromikova, V.; Jiang, K.; Strohmeier, S.; Arunkumar, G.A.; Tan, J.; Bhavsar, D.; Capuano, C.; Kirkpatrick, E.; et al. SARS-CoV-2 Seroconversion in Humans: A Detailed Protocol for a Serological Assay, Antigen Production, and Test Setup. Curr. Protoc. Microbiol. 2020, 57, e100. [CrossRef]

71. Bates, T.A.; Weinstein, J.B.; Farley, S.; Leier, H.C.; Messer, W.B.; Tafesse, F.G. Cross-reactivity of SARS-CoV structural protein antibodies against SARS-CoV-2. Cell Rep. 2021, 34, 108737. [CrossRef]

72. Sterlin, D.; Mathian, A.; Miyara, M.; Mohr, A.; Anna, F.; Claër, L.; Quentric, P.; Fadlallah, J.; Devilliers, H.; Ghillani, P. IgA dominates the early neutralizing antibody response to SARS-CoV-2. Sci. Transl. Med. 2021, 13, eabd2223. [CrossRef]

73. U.S. Food and Drug Administration. In Vitro Diagnostics EUAs; U.S. Food and Drug Administration: Silver Spring, MD, USA, 2020.

74. BinaxNOW COVID-19 Ag Card. Abbott Diagnostics Scarborough, Inc. Available online: https://www.fda.gov/media/141570 / download (accessed on 20 July 2021).

75. CareStart COVID-19 Anti-gen Test. Access Bio, Inc. Available online: https://www.fda.gov/media/142919/download (accessed on 20 July 2021).

76. Lumira Dx SARS-CoV-2 Ag Test. Lumira Dx UK Ltd. Available online: https://www.fda.gov/media/141302/download (accessed on 20 July 2021).

77. Sofia $2 \mathrm{Flu}+$ SARS Antigen FIA, Quidel Corporation. Available online: https://www.fda.gov/media/142704/download (accessed on 20 July 2021).

78. Biohit SARS-CoV-2 IgM/IgG Antibody Test Kit. Biohit Healthcare (Hefei) Co., Ltd. Available online: https://www.fda.gov/ media/139283/download (accessed on 20 July 2021).

79. COVID-19 IgG/IgM Rapid Test Cassette. Healgen Scientific LLC. Available online: https://www.fda.gov/media/138438 / download (accessed on 20 July 2021).

80. Diagnostic Kit for IgM/IgG Antibody to Coronavirus (SARS-CoV-2). Zhuhai Livzon Diagnostics Inc. Available online: http: / / www.livzondiagnostics.com/en-us/info/17.html (accessed on 20 July 2021).

81. qSARS-CoV-2 IgG/IgM Rapid Test. Cellex Inc. Available online: https://www.fda.gov/media/136622/download (accessed on 20 July 2021).

82. Sienna-Clarity COVIBLOCK COVID-19 IgG/IgM Rapid Test Cassette. Salofa Oy. Available online: https://www.fda.gov/media/ 140082/download (accessed on 20 July 2021).

83. SARS-CoV-2 Ig-GIgM Antibody Rapid Test Kit. Lumigenex Co., Ltd. Available online: http://www.lumigenex.com/dynamic/ 363.html (accessed on 20 July 2021).

84. SARS-CoV-2 Antibody Test. Guangzhou Wondfo Biotech Co., Ltd. Available online: https://www.bilcare.com/SARS-CoV-2\%20 Antibody\%20Test\%20(Lateral\%20Flow\%20Method).pdf (accessed on 20 July 2021).

85. RapCov Rapid COVID-19 Test. ADVAITE, Inc. Available online: https://www.fda.gov/media/145080/download (accessed on 20 July 2021).

86. Rapid COVID-19 IgM/IgG Combo Test Kit. Megna Health, Inc. Available online: https://www.fda.gov/media/140297 / download (accessed on 20 July 2021).

87. Bastos, M.L.; Tavaziva, G.; Abidi, S.K.; Campbell, J.R.; Haraoui, L.-P.; Johnston, J.C.; Lan, Z.; Law, S.; MacLean, E.; Trajman, A. Diagnostic accuracy of serological tests for COVID-19: Systematic review and meta-analysis. BMJ 2020, 370. [CrossRef]

88. Liu, Y.; Zhan, L.; Qin, Z.; Sackrison, J.; Bischof, J.C. Ultrasensitive and highly specific lateral flow assays for point-of-care diagnosis. ACS Nano 2021, 15, 3593-3611. [CrossRef]

89. Chen, P.; Gates-Hollingsworth, M.; Pandit, S.; Park, A.; Montgomery, D.; AuCoin, D.; Gu, J.; Zenhausern, F. Paper-based Vertical Flow Immunoassay (VFI) for detection of bio-threat pathogens. Talanta 2019, 191, 81-88. [CrossRef]

90. Sajid, M.; Kawde, A.-N.; Daud, M. Designs, formats and applications of lateral flow assay: A literature review. J. Saudi Chem. Soc. 2015, 19, 689-705. [CrossRef]

91. Sharma, A.; Tok, A.I.Y.; Lee, C.; Ganapathy, R.; Alagappan, P.; Liedberg, B. Magnetic field assisted preconcentration of biomolecules for lateral flow assaying. Sens. Actuators B Chem. 2019, 285, 431-437. [CrossRef]

92. Mashayekhi, F.; Le, A.M.; Nafisi, P.M.; Wu, B.M.; Kamei, D.T. Enhancing the lateral-flow immunoassay for detection of proteins using an aqueous two-phase micellar system. Anal. Bioanal. Chem. 2012, 404, 2057-2066. [CrossRef]

93. Moghadam, B.Y.; Connelly, K.T.; Posner, J.D. Two orders of magnitude improvement in detection limit of lateral flow assays using isotachophoresis. Anal. Chem. 2015, 87, 1009-1017. [CrossRef]

94. Kim, J.; Mohamed, M.A.A.; Zagorovsky, K.; Chan, W.C. State of diagnosing infectious pathogens using colloidal nanomaterials. Biomaterials 2017, 146, 97-114. [CrossRef]

95. Wang, C.; Shi, D.; Wan, N.; Yang, X.; Liu, H.; Gao, H.; Zhang, M.; Bai, Z.; Li, D.; Dai, E. Development of spike protein-based fluorescence lateral flow assay for the simultaneous detection of SARS-CoV-2 specific IgM and IgG. Analyst 2021, 146, 3908-3917. [CrossRef]

96. Hui, Y.Y.; Chen, O.J.; Lin, H.-H.; Su, Y.-K.; Chen, K.Y.; Wang, C.-Y.; Hsiao, W.W.-W.; Chang, H.-C. Magnetically Modulated Fluorescence of Nitrogen-Vacancy Centers in Nanodiamonds for Ultrasensitive Biomedical Analysis. Anal. Chem. 2021, 93, 7140-7147. [CrossRef]

97. Wang, Z.; Zheng, Z.; Hu, H.; Zhou, Q.; Liu, W.; Li, X.; Liu, Z.; Wang, Y.; Ma, Y. A point-of-care selenium nanoparticle-based test for the combined detection of anti-SARS-CoV-2 IgM and IgG in human serum and blood. Lab Chip 2020, 20, 4255-4261. [CrossRef] 
98. Tjon Kon Fat, E.M.; Abrams, W.R.; Niedbala, R.S.; Corstjens, P.L. Lateral flow sandwich assay utilizing upconverting phosphor (UCP) reporters. Methods Cell Biol. 2012, 112, 203-234.

99. Xu, H.; Chen, J.; Birrenkott, J.; Zhao, J.X.; Takalkar, S.; Baryeh, K.; Liu, G. Gold-nanoparticle-decorated silica nanorods for sensitive visual detection of proteins. Anal. Chem. 2014, 86, 7351-7359. [CrossRef]

100. Liu, X.; Yang, J.; Li, Q.; Wang, Y.; Wang, Y.; Li, G.; Shi, J.; Ding, P.; Guo, J.; Deng, R. A strip test for the optical determination of influenza virus $\mathrm{H} 3$ subtype using gold nanoparticle coated polystyrene latex microspheres. Microchim. Acta 2020, 187, 306. [CrossRef]

101. Wang, J.; Meng, H.-M.; Chen, J.; Liu, J.; Zhang, L.; Qu, L.; Li, Z.; Lin, Y. Quantum Dot-Based Lateral Flow Test Strips for Highly Sensitive Detection of the Tetanus Antibody. ACS Omega 2019, 4, 6789-6795. [CrossRef]

102. He, H.; Liu, B.; Wen, S.; Liao, J.; Lin, G.; Zhou, J.; Jin, D. Quantitative Lateral Flow Strip Sensor Using Highly Doped Upconversion Nanoparticles. Anal. Chem. 2018, 90, 12356-12360. [CrossRef]

103. Qie, Z.; Liu, Q.; Yan, W.; Gao, Z.; Meng, W.; Xiao, R.; Wang, S. Universal and ultrasensitive Immunochromatographic assay by using an antigen as a Bifunctional element and Antialbumin antibody on a test line. Anal. Chem. 2019, 91, 9530-9537. [CrossRef]

104. You, P.-Y.; Li, F.-C.; Liu, M.-H.; Chan, Y.-H. Colorimetric and fluorescent dual-mode immunoassay based on plasmon-enhanced fluorescence of polymer dots for detection of PSA in whole blood. ACS Appl. Mater. Interfaces 2019, 11, 9841-9849. [CrossRef]

105. Hu, J.; Zhang, Z.-L.; Wen, C.-Y.; Tang, M.; Wu, L.-L.; Liu, C.; Zhu, L.; Pang, D.-W. Sensitive and quantitative detection of C-reaction protein based on immunofluorescent nanospheres coupled with lateral flow test strip. Anal. Chem. 2016, 88, 6577-6584. [CrossRef]

106. Hsiao, W.W.-W.; Hui, Y.Y.; Tsai, P.-C.; Chang, H.-C. Fluorescent nanodiamond: A versatile tool for long-term cell tracking, super-resolution imaging, and nanoscale temperature sensing. Acc. Chem. Res. 2016, 49, 400-407. [CrossRef]

107. Hsiao, W.W.-W.; Lin, H.-H.; Chang, H.-C. Diamond Nanoparticles for Drug Delivery and Monitoring. In Carbon-Based Nanosensor Technology; Springer: Berlin/Heidelberg, Germany, 2017; pp. 119-140.

108. Hsiao, W.W.-W.; Lin, H.-H.; Hsieh, F.-J.; Chang, H.-C. Surface-Modified Nanodiamonds. In Carbon Nanomaterials Sourcebook: Graphene, Fullerenes, Nanotubes, and Nanodiamonds; Sattler, K.D., Ed.; CRC Press: Boca Raton, FL, USA, 2016; Volume 1, pp. 525-542.

109. Hui, Y.Y.; Hsiao, W.W.-W.; Haziza, S.; Simonneau, M.; Treussart, F.; Chang, H.-C. Single particle tracking of fluorescent nanodiamonds in cells and organisms. Curr. Opin. Solid State Mater. Sci. 2017, 21, 35-42. [CrossRef]

110. Yu, S.-J.; Kang, M.-W.; Chang, H.-C.; Chen, K.-M.; Yu, Y.-C. Bright fluorescent nanodiamonds: No photobleaching and low cytotoxicity. J. Am. Chem. Soc. 2005, 127, 17604-17605. [CrossRef] [PubMed]

111. Su, L.-J.; Wu, M.-S.; Hui, Y.Y.; Chang, B.-M.; Pan, L.; Hsu, P.-C.; Chen, Y.-T.; Ho, H.-N.; Huang, Y.-H.; Ling, T.-Y. Fluorescent nanodiamonds enable quantitative tracking of human mesenchymal stem cells in miniature pigs. Sci. Rep. 2017, 7, 45607. [CrossRef] [PubMed]

112. Doherty, M.W.; Manson, N.B.; Delaney, P.; Jelezko, F.; Wrachtrup, J.; Hollenberg, L.C. The nitrogen-vacancy colour centre in diamond. Phys. Rep. 2013, 528, 1-45. [CrossRef]

113. Tsai, P.-C.; Chen, O.Y.; Tzeng, Y.-K.; Hui, Y.Y.; Guo, J.Y.; Wu, C.-C.; Chang, M.-S.; Chang, H.-C. Gold/diamond nanohybrids for quantum sensing applications. EPJ Quantum Technol. 2015, 2, 19. [CrossRef]

114. Chang, B.M.; Lin, H.H.; Su, L.J.; Lin, W.D.; Lin, R.J.; Tzeng, Y.K.; Lee, R.T.; Lee, Y.C.; Yu, A.L.; Chang, H.C. Highly fluorescent nanodiamonds protein-functionalized for cell labeling and targeting. Adv. Funct. Mater. 2013, 23, 5737-5745. [CrossRef]

115. Fu, C.-C.; Lee, H.-Y.; Chen, K.; Lim, T.-S.; Wu, H.-Y.; Lin, P.-K.; Wei, P.-K.; Tsao, P.-H.; Chang, H.-C.; Fann, W. Characterization and application of single fluorescent nanodiamonds as cellular biomarkers. Proc. Natl. Acad. Sci. USA 2007, 104, 727-732. [CrossRef]

116. Igarashi, R.; Yoshinari, Y.; Yokota, H.; Sugi, T.; Sugihara, F.; Ikeda, K.; Sumiya, H.; Tsuji, S.; Mori, I.; Tochio, H. Real-time background-free selective imaging of fluorescent nanodiamonds in vivo. Nano Lett. 2012, 12, 5726-5732. [CrossRef]

117. Hsu, T.-C.; Liu, K.-K.; Chang, H.-C.; Hwang, E.; Chao, J.-I. Labeling of neuronal differentiation and neuron cells with biocompatible fluorescent nanodiamonds. Sci. Rep. 2014, 4, 5004. [CrossRef]

118. Cordina, N.M.; Sayyadi, N.; Parker, L.M.; Everest-Dass, A.; Brown, L.J.; Packer, N.H. Reduced background autofluorescence for cell imaging using nanodiamonds and lanthanide chelates. Sci. Rep. 2018, 8, 4521. [CrossRef]

119. Hui, Y.Y.; Su, L.-J.; Chen, O.Y.; Chen, Y.-T.; Liu, T.-M.; Chang, H.-C. Wide-field imaging and flow cytometric analysis of cancer cells in blood by fluorescent nanodiamond labeling and time gating. Sci. Rep. 2014, 4, 5574. [CrossRef]

120. Feuerstein, G.Z.; Mansfield, M.A.; Lelkes, P.I.; Alesci, S.; Marcinkiewicz, C.; Butlin, N.; Sternberg, M. The Use of Near-Infrared Light-Emitting Fluorescent Nanodiamond Particles to Detect Ebola Virus Glycoprotein: Technology Development and Proof of Principle. Int. J. Nanomed. 2020, 15, 7583. [CrossRef]

121. Miller, B.S.; Bezinge, L.; Gliddon, H.D.; Huang, D.; Dold, G.; Gray, E.R.; Heaney, J.; Dobson, P.J.; Nastouli, E.; Morton, J.J. Spin-enhanced nanodiamond biosensing for ultrasensitive diagnostics. Nature 2020, 587, 588-593. [CrossRef]

122. Anand, T.; Virmani, N.; Bera, B.C.; Vaid, R.K.; Vashisth, M.; Bardajatya, P.; Kumar, A.; Tripathi, B.N. Phage Display Technique as a Tool for Diagnosis and Antibody Selection for Coronaviruses. Curr. Microbiol. 2021, 78, 1124-1134. [CrossRef]

123. Parmley, S.F.; Smith, G.P. Antibody-selectable filamentous fd phage vectors: Affinity purification of target genes. Gene 1988, 73 , 305-318. [CrossRef]

124. Bertoglio, F.; Fühner, V.; Ruschig, M.; Heine, P.A.; Abassi, L.; Klünemann, T.; Rand, U.; Meier, D.; Langreder, N.; Steinke, S.; et al. A SARS-CoV-2 neutralizing antibody selected from COVID-19 patients binds to the ACE2-RBD interface and is tolerant to most known RBD mutations. Cell Rep. 2021, 36, 109433. [CrossRef] 
125. Bertoglio, F.; Meier, D.; Langreder, N.; Steinke, S.; Rand, U.; Simonelli, L.; Heine, P.A.; Ballmann, R.; Schneider, K.-T.; Roth, K.D.R.; et al. SARS-CoV-2 neutralizing human recombinant antibodies selected from pre-pandemic healthy donors binding at RBD-ACE2 interface. Nat. Commun. 2021, 12, 1577. [CrossRef]

126. Li, W.; Chen, C.; Drelich, A.; Martinez, D.R.; Gralinski, L.E.; Sun, Z.; Schäfer, A.; Kulkarni, S.S.; Liu, X.; Leist, S.R.; et al. Rapid identification of a human antibody with high prophylactic and therapeutic efficacy in three animal models of SARS-CoV-2 infection. Proc. Natl. Acad. Sci. USA 2020, 117, 29832-29838. [CrossRef]

127. Somasundaram, R.; Choraria, A.; Antonysamy, M. An approach towards development of monoclonal IgY antibodies against SARS CoV-2 spike protein (S) using phage display method: A review. Int. Immunopharmacol. 2020, 85, 106654. [CrossRef]

128. Thirumalai, D.; Visaga Ambi, S.; Vieira-Pires, R.S.; Xiaoying, Z.; Sekaran, S.; Krishnan, U. Chicken egg yolk antibody (IgY) as diagnostics and therapeutics in parasitic infections-A review. Int. J. Biol. Macromol. 2019, 136, 755-763. [CrossRef]

129. Broughton, J.P.; Deng, X.; Yu, G.; Fasching, C.L.; Servellita, V.; Singh, J.; Miao, X.; Streithorst, J.A.; Granados, A.; SotomayorGonzalez, A. CRISPR-Cas12-based detection of SARS-CoV-2. Nat. Biotechnol. 2020, 38, 870-874. [CrossRef] [PubMed]

130. Hou, T.; Zeng, W.; Yang, M.; Chen, W.; Ren, L.; Ai, J.; Wu, J.; Liao, Y.; Gou, X.; Li, Y. Development and evaluation of a rapid CRISPR-based diagnostic for COVID-19. PLoS Pathog. 2020, 16, e1008705. [CrossRef] [PubMed]

131. Wang, X.; Xiong, E.; Tian, T.; Cheng, M.; Lin, W.; Wang, H.; Zhang, G.; Sun, J.; Zhou, X. Clustered regularly interspaced short palindromic repeats/Cas9-mediated lateral flow nucleic acid assay. ACS Nano 2020, 14, 2497-2508. [CrossRef] [PubMed]

132. Schramm, E.C.; Staten, N.R.; Zhang, Z.; Bruce, S.S.; Kellner, C.; Atkinson, J.P.; Kyttaris, V.C.; Tsokos, G.C.; Petri, M.; Connolly, E.S. A quantitative lateral flow assay to detect complement activation in blood. Anal. Biochem. 2015, 477, 78-85. [CrossRef]

133. Mendels, D.-A.; Dortet, L.; Emeraud, C.; Oueslati, S.; Girlich, D.; Ronat, J.-B.; Bernabeu, S.; Bahi, S.; Atkinson, G.J.H.; Naas, T. Using artificial intelligence to improve COVID-19 rapid diagnostic test result interpretation. Proc. Natl. Acad. Sci. USA 2021, 118, e2019893118. [CrossRef]

134. LooK SPOT AI COVID-19 Antigen Rapid Test. Available online: https:/ /www.aetoswire.com/news/12964/en (accessed on 4 July 2021).

135. Huang, S.; Yang, J.; Fong, S.; Zhao, Q. Artificial intelligence in the diagnosis of COVID-19: Challenges and perspectives. Int. J. Biol. Sci. 2021, 17, 1581-1587. [CrossRef]

136. Mei, X.; Lee, H.-C.; Diao, K.; Huang, M.; Lin, B.; Liu, C.; Xie, Z.; Ma, Y.; Robson, P.M.; Chung, M.; et al. Artificial intelligenceenabled rapid diagnosis of COVID-19 patients. medRxiv 2020. [CrossRef]

137. Fozouni, P.; Son, S.; Díaz de León Derby, M.; Knott, G.J.; Gray, C.N.; D’Ambrosio, M.V.; Zhao, C.; Switz, N.A.; Kumar, G.R.; Stephens, S.I.; et al. Amplification-free detection of SARS-CoV-2 with CRISPR-Cas13a and mobile phone microscopy. Cell 2021, 184, 323-333.e9. [CrossRef]

138. Chung, S.; Breshears, L.E.; Perea, S.; Morrison, C.M.; Betancourt, W.Q.; Reynolds, K.A.; Yoon, J.-Y. Smartphone-Based Paper Microfluidic Particulometry of Norovirus from Environmental Water Samples at the Single Copy Level. ACS Omega 2019, 4, 11180-11188. [CrossRef]

139. Ning, B.; Yu, T.; Zhang, S.; Huang, Z.; Tian, D.; Lin, Z.; Niu, A.; Golden, N.; Hensley, K.; Threeton, B.; et al. A smartphone-read ultrasensitive and quantitative saliva test for COVID-19. Sci. Adv. 2021, 7, eabe3703. [CrossRef]

140. Ming, K.; Kim, J.; Biondi, M.J.; Syed, A.; Chen, K.; Lam, A.; Ostrowski, M.; Rebbapragada, A.; Feld, J.J.; Chan, W.C.W. Integrated Quantum Dot Barcode Smartphone Optical Device for Wireless Multiplexed Diagnosis of Infected Patients. ACS Nano 2015, 9 , 3060-3074. [CrossRef] 